\title{
26. STRATIGRAPHIC SYNTHESIS OF THE DSDP-ODP SITES IN THE SHIKOKU BASIN, NANKAI TROUGH, AND ACCRETIONARY PRISM ${ }^{1}$
}

\author{
Kevin T. Pickering, ${ }^{2}$ Michael B. Underwood, ${ }^{3}$ and Asahiko Taira ${ }^{4}$
}

\begin{abstract}
The stratigraphy of the Deep Sea Drilling Project/Ocean Drilling Program drill sites in the northern Shikoku Basin and Nankai Trough area are reviewed in the context of data from ODP Site 808, and interpreted with generalized depositional models for the Nankai Trough and Shikoku backarc basin. Backarc rifting between about 27 and 14 Ma caused the partitioning of the Shikoku Basin early in its history into a western (e.g., DSDP Sites 442 and 297) and eastern Shikoku Basin (e.g., DSDP Sites 443 and 444), separated by the linear and topographically high spreading ridge and the Kinan seamount chain. Pliocene terrigenous turbidites recovered at DSDP Site 297 appear to have been restricted to southwest of the spreading center; therefore, terrigenous turbidity currents coming from the Suruga Trough, to the east-northeast, do not appear to have been capable of overspilling the ridge crest, and if they overspilled the confines of the trench would have been confined to the eastern Shikoku Basin. We therefore believe that the terrigenous turbidites at Site 297 probably were delivered to the Shikoku Basin via Ashizuri Canyon at the western end of Shikoku, which lacks volcanoes of this time interval and is therefore a better candidate source for the more quartzofeldspathic sands rather than the Izu collision zone. Alternatively, another viable sediment source for these terrigenous turbidite sands is via a canyon from Kyushu. The ODP Site 808 stratigraphy shows that at about 300 k.y., major terrigenous sediment overspill occurred across the subducting, extinct, spreading ridge crest, marked by a prominent debris-flow event, associated with the abrupt southwestward progradation of the sandy trench-wedge turbidite system. As a consequence, the western and eastern parts of the Nankai Trough became linked depositional basins for the accumulation of terrigenous sands derived mainly from the Izu collision zone.

At ODP Site 808, the geochemistry suggests that the source of the approximately 14-Ma rhyolitic pyroclastic unit immediately overlying the basaltic oceanic basement appears to have been different from that for the younger ash units higher up in the succession. A probable source for the rhyolitic pyroclastic unit may be related to the onland geology in Japan where circa-14-Ma unroofed granites occur on Kii Peninsula and in Kyushu. On Kii Peninsula, considerable volumes of middle Miocene pyroclastics remain, and therefore provide good temporal and spatial correlatives for the pyroclastics encountered at the base of ODP Site 808. Some of the subaqueous pyroclastics at Site 808 may also have come from submerged explosive volcanic centers to give reworked deposits. The Miocene volcaniclastics recovered from DSDP Site 297 also may be related to the rhyolites at ODP Site 808.
\end{abstract}

\section{INTRODUCTION}

The Nankai Trough region (Fig. 1) is one of the most studied Cenozoic active convergent plate margins. It is a good example of a trench wedge associated with a voluminous supply of terrigenous sandy turbidites, which constitute the uppermost $600 \mathrm{~m}$ of the stratigraphy. To the south of the Nankai Trough, the Shikoku Basin is an elongate backarc basin forming the northeastern part of the Philippine Sea Plate. From the late Oligocene to middle Miocene, seafloor spreading occurred behind the Izu-Bonin arc-trench system to progressively isolate the Kyushu-Palau Ridge (Karig, Ingle, et al., 1975; Marauchi and Asanuma, 1974, 1977; Moore and Karig, 1976; White et al., 1980; Chamot-Rooke et al., 1987 and references therein). Magnetic anomaly data suggest that between 14 and $12 \mathrm{Ma}$, a late phase of north-south spreading was limited to the axial northernmost Shikoku Basin, also associated with a counterclockwise rotation of the spreading direction (Chamot-Rooke et al., 1987). Figure 2 is a summary of the plate-tectonic history of this region, using data from Taira (1986), Hibbard and Karig (1990), and Koyama (1991).

During the Oligocene-Miocene, about 27-14 Ma, backarc rifting occurred behind the Izu-Bonin Arc to produce the Shikoku Basin and western Kyushu-Palau Ridge. The continental margin of southern Honshu and Shikoku was probably dominated by strike-slip tectonics. At about 15-14 Ma, the Sea of Japan and Okhotsk Sea marginal basins

\footnotetext{
${ }^{1}$ Hill, I.A., Taira, A., Firth, J.V., et al., 1993. Proc. ODP, Sci. Results, 131: College Station, TX (Ocean Drilling Program).

${ }^{2}$ Department of Geology, University of Leicester, Leicester LE1 7RH, United Kingdom.

${ }^{3}$ Department of Geology, University of Missouri, Columbia, MO 65211, U.S.A.

${ }^{4}$ Ocean Research Institute, University of Tokyo, 1-15-1 Minamidai, Nakano-ku, Tokyo 164, Japan.
}

underwent a phase of rapid seafloor spreading, although opening began much earlier at about $26 \mathrm{Ma}$. Northern Honshu and Hokkaido rotated counterclockwise, whereas Kyushu, Shikoku, and southern Honshu rotated clockwise. These events appear to have occurred within the space of only a few million years. Geological evidence from the Shimanto belt has led Hibbard and Karig (1990) to postulate that (1) during the opening of the Shikoku backarc basin, from 26 to $15 \mathrm{Ma}$, it was separated from the Japanese margin by an extension of the Pacific Plate, and (2) the Shikoku Basin spreading center collided with southwest Japan at about $15 \mathrm{Ma}$, at which time the trench-trenchtrench (TTT) triple junction was probably initiated. In this scenario, a transform boundary is interpreted to separate the Pacific Plate from the northern edge of the Shikoku Basin, on the Philippine Sea Plate (Hibbard and Karig, 1990). Koyama (1991) summarizes the paleomagnetic evidence, including data from the recent Leg 126, to support a clockwise rotation of the Shikoku Basin and associated Izu-Bonin island arc (and Kyushu-Palau Ridge), associated with the opening of the Sea of Japan. The paleomagnetic data from land and marine sites shows large $\left(30^{\circ}-100^{\circ}\right)$ clockwise deflections of declinations in Eocene to middle Miocene rocks, consistent with large clockwise rotation and northward drift (greater than $10^{\circ}$ of latitude) for the entire Philippine Sea Plate between about 27 and $17 \mathrm{Ma}$ (Koyama, 1991). During the late Miocene, the Izu-Bonin Arc began to impinge against the Honshu Arc to generate the Izu collision zone (ICZ). Episodic collision-accretion occurred to amalgamate imbricated crustal slices from the Izu-Bonin Arc onto the leading edge of the southeast part of the Honshu Arc. In southeast Honshu, the arc-arc collision, which is still continuing, caused the bending of the geological belts, such as in the Fossa Magna. In the late Miocene to Holocene, backarc oblique, dextral rifting took place in the Okinawa trough, with the propagation of the rift system as far north as Kyushu. 


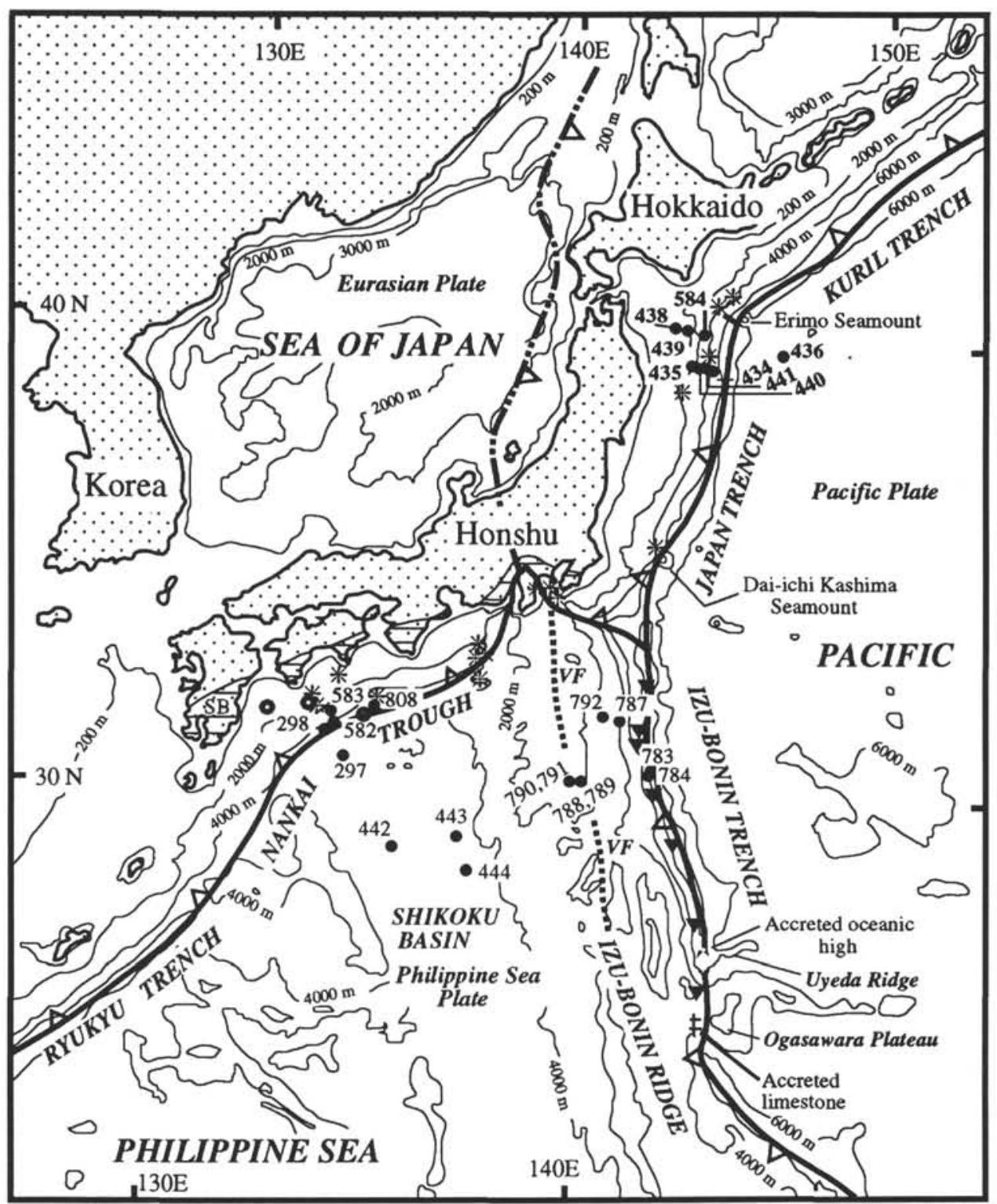

\begin{tabular}{|llll|}
\hline Key & & Subduction zone + \\
subduction polarity
\end{tabular}

Figure 1. Location map of DSDP/ODP sites in the northern Shikoku Basin and Nankai Trough region.

Many models predict the stratigraphy at active convergent plate margins where normal-thickness oceanic crust is subducted (e.g., Piper et al., 1973; Schweller and Kulm, 1978; Dickinson and Seely, 1979; Thornburg and Kulm, 1987; Underwood, 1991), but there are few for regions of arc-ridge and arc-arc collision (e.g., Collot et al., 1985; Fisher et al., 1986; Soh et al., 1990). In the case of subducting normal-thickness oceanic crust, a feature common to all depositional models is the development of a classic coarsening-upward sequence from open-ocean, pelagic sediments on the oceanic plate to coarsegrained, terrigenous (and volcaniclastic), trench-fill sediments. Such depositional models tend to be based on relatively simple forearcs with linear trenches and a number of discrete sediment entry points (canyons) along their length; also, they do not involve the subduction of a backarc basin and spreading center, as is the case for the Nankai Trough, although the sediment distribution for the Shikoku Basin was schematically shown by White et al. (1980, fig. 20).

The purpose of this study is to review the stratigraphic data of the Deep Sea Drilling Project (DSDP) and Ocean Drilling Program (ODP) sites in the Nankai Trough, forearc, and Shikoku Basin, and other appropriate regional data, and to develop a depositional model for 
sedimentation in a forearc associated with the subduction of a backarc basin. After reviewing the stratigraphy of ODP Site 808 (Nankai Trough), the following sections briefly summarize the results from previous drilling in the northern Shikoku Basin and Nankai Trough.

\section{SITE 808, NANKAI TROUGH}

In addition to the four previous DSDP/ODP cruises to the Nankai Trough region (Legs 31, 58, 87A, and 131, discussed below), numerous seismic sections and conventional coring traverses have been made across the area (e.g., Boggs, 1984; Kagami, 1985; Le Pichon et al., 1987a, 1987b, Okuda and Honza, 1988; Shimamura, 1989; Moore et al., 1990).

In the vicinity of Site 808 , the high-resolution IZANAGI sidescan sonar site-survey image shows the lower slope of the Nankai accretionary prism dissected by many thrusts breaking the seafloor behind the deformation front (Fig. 3). The relatively smooth floor of Nankai Trough is visible, together with mud volcanoes and recent sediment slides (including the ones drilled at Site 808). Site 808 was drilled into a prominent sediment slide deposit near the toe of the Nankai Trough accretionary prism (Figs. 3 and 4 ) near the subducting axis of the extinct oceanic spreading center of the Shikoku Basin (ChamotRooke et al., 1987; Le Pichon et al., 1987b).

Line NKT62-8 (Fig. 4B, line A; Moore, Karig, et al., 1991; Moore and Shipboard Scientific Party, 1991), the principal multichannel seismic line used to convey the prism perpendicular to the deformation front (Moore et al., 1990; Taira, Hill, Firth, et al., 1991), shows the essentially sheet-like geometry of the trench-wedge sandy turbidites onlapping the outer trench slope; the integrity of individual reflectors are lost as they approach the outer slope and "shale out." The underlying hemipelagic deposits of the Shikoku Basin, on the downgoing ocean plate, show abundant evidence of extension as high-angle normal faults cutting the stratigraphy. The normal faults are an integral tectonic feature associated with the extinct spreading center of the Shikoku backarc basin (Kaiko I Research Group, 1986).

The prominent reflector on line NKT62-8, which appears to define the present base of the trench-wedge sandy turbidites, can be correlated back into the front of the accretionary prism and, from drilling at Site 808 , is correlated with a horizon containing a matrix-supported debrisflow deposit. The debris-flow deposit, and its correlative basinward reflector, appears to be a major impedance contrast and therefore one of the main seismic events. With its base occurring at 263.4 meters below seafloor (mbsf) (about 0.3 Ma, Fig. 5) and $409.5 \mathrm{mbsf}$, this deposit was used to determine the offset of $145 \mathrm{~m}$ across the frontal thrust (Shipboard Scientific Party, 1991c).

Seismic lines across other parts of the Nankai Trough and accretionary prism in the vicinity of Site 808 also show the debris-flow deposit reflector, indicating that the horizon containing this deposit represents a major tectono-stratigraphic, probably seismogenic, event in the area.

The trench axis-parallel seismic reflection line KT84-15-L1 (Fig. 4) shows that the onset of coarse, sandy turbidite deposition in the trench in the Site 808 area was probably delayed until the bathymetrically deeper, off-ridge-axis basin to the northeast (sourceward) was infilled. The major sediment overspill event across the buried, topographically higher subducting ridge axis is marked by the debris-flow event. This inference raises intriguing questions about the origin of the debris-flow deposit and its temporal relationship with the abrupt southwestward progradation of the sandy trench-wedge turbidite system (see below). We speculate that a substantially increased volume, and greater caliber, of sediment was supplied into the Nankai Trough at this time, and that it was delivered at a rate sufficient to cause effective oversupply to the bathymetric lows along the trench. Consequently, the trench turbidite wedge, constructed by flows from the eastern ends of Nankai Trough, rapidly prograded over the topographic high associated with the subducting extinct spreading center of the Shikoku Basin. The prominent seismic reflector associated with this major phase of progradation probably does not represent a single, discrete, isochronous depositional event but, rather, a series of temporally related sediment mass flows and sediment gravity flows that delivered coarse sediments to the trench.

In the Shikoku Basin, isopach mapping of sediment thickness to acoustic basement suggests that the clastic wedges may have three discrete provenances: the western Kyushu-Palau Ridge, the eastern Izu-Bonin island arc, and the northern mainland Japan or Honshu Arc (Karig, 1975; White et al., 1980, fig. 20).

\section{Site 808 Lithostratigraphy}

Site 808 , with a total penetration of 1327 meters below seafloor (mbsf), represents the first complete drilling through an accretionary prism and the subducting hemipelagic and pelagic sediments, to the basaltic oceanic basement of the subducting plate (Fig. 6; Shipboard Scientific Party, 1991a, b, c).

This section briefly reviews the sedimentology and stratigraphy of Site 808. A detailed structural synthesis is provided by Byrne et al. (this volume), and is therefore not considered further in this chapter. Detailed mineralogical and geochemical syntheses are provided for the sediments by Underwood et al. (this volume), the aqueous geochemistry by Gieskes et al. (this volume), the volcanic ashes by Masuda et al. (this volume), and the mud geochemistry, including rare earth elements, by Pickering et al. (this volume). The lithologies recovered in Holes $808 \mathrm{~A}, 808 \mathrm{~B}$, and $808 \mathrm{C}$ comprise six discrete units, two of which contain subunits (Fig. 6). The units/subunits were differentiated on the basis of visual core descriptions, grain size, bed-layer thickness, and mineralogy. The abundance of the turbidites and ashes/tuffs was used as the main criterion to define the lithostratigraphic units at Site 808 . The following lithological units define the stratigraphy from top to bottom of Site 808 (Fig. 6):

Unit I: Lower-slope apron (0-20.55 mbsf),

Unit II: Trench-fill deposits (20.55-556.8 mbsf),

Subunit IIa: Upper axial-trench sandy deposits (20.55-120.6 mbsf),

Subunit IIb: Lower axial-trench silty deposits (120.6-263.4 mbsf),

Subunit IIc: Outer marginal trench deposits (409.54-556.8 mbsf),

Unit III: Trench to basin transitional deposits (556.8-618.47 mbsf),

Unit IV: Shikoku Basin deposits (618.47-1243 mbsf),

Subunit IVa: Upper Shikoku Basin deposits (618.47-823.74 mbsf),

Subunit IVb: Lower Shikoku Basin deposits (823.74-1243 mbsf),

Unit V: Acidic volcaniclastic deposits (1243-1289.9 mbsf),

Unit VI: Basaltic basement (1289.9-1327 mbsf).

Stratigraphic analysis shows that a distinct, matrix-supported mudstone-pebble conglomerate is duplicated across the frontal thrust. The base of the recovered conglomerate occurs at 263.4 mbsf and 409.54 mbsf (Fig. 7), giving a vertical offset of $145 \mathrm{~m}$. The repetition of a distinct yellowish carbonate (altered nannofossil ooze) below the conglomerate at 289.7 and at 437.33 mbsf gives a similar vertical offset of $147.63 \mathrm{~m}$. A value of $145-\mathrm{m}$ stratigraphic duplication is used in this paper as an approximation of the vertical displacement along the main frontal thrust.

In Hole 808B, the frontal thrust appears to occur between 336.0 and $340.6 \mathrm{mbsf}$, whereas in Hole $808 \mathrm{C}$, landward of Hole $808 \mathrm{~B}$, the thrust zone extends from approximately $356.2-394.8 \mathrm{mbsf}$. The most highly fractured lithologies, showing a scaly fabric, occur in the interval between about 366 and 376 mbsf. Based on the geometry of overturned beds within Core 131-808C-8R, and vertical to subvertical bedding in the lower part of Core 131-808C-8R and throughout Core 131-808C-9R, the zone of maximum displacement of the main frontal thrust appears to be at approximately $366 \mathrm{mbsf}$. The inorganic geochemistry shows clearly defined anomalies in elements such as $\mathrm{Ca}$, $\mathrm{Mg}$, and $\mathrm{Li}$ at about $365 \mathrm{mbsf}$ (Shipboard Scientific Party, 1991c). In this study, a depth of about 365 mbsf is taken as the position of the frontal thrust. Thus, the frontal thrust repeats about $145 \mathrm{~m}$ of stratigraphy at Site 808 , from approximately 365 to 220 mbsf. 

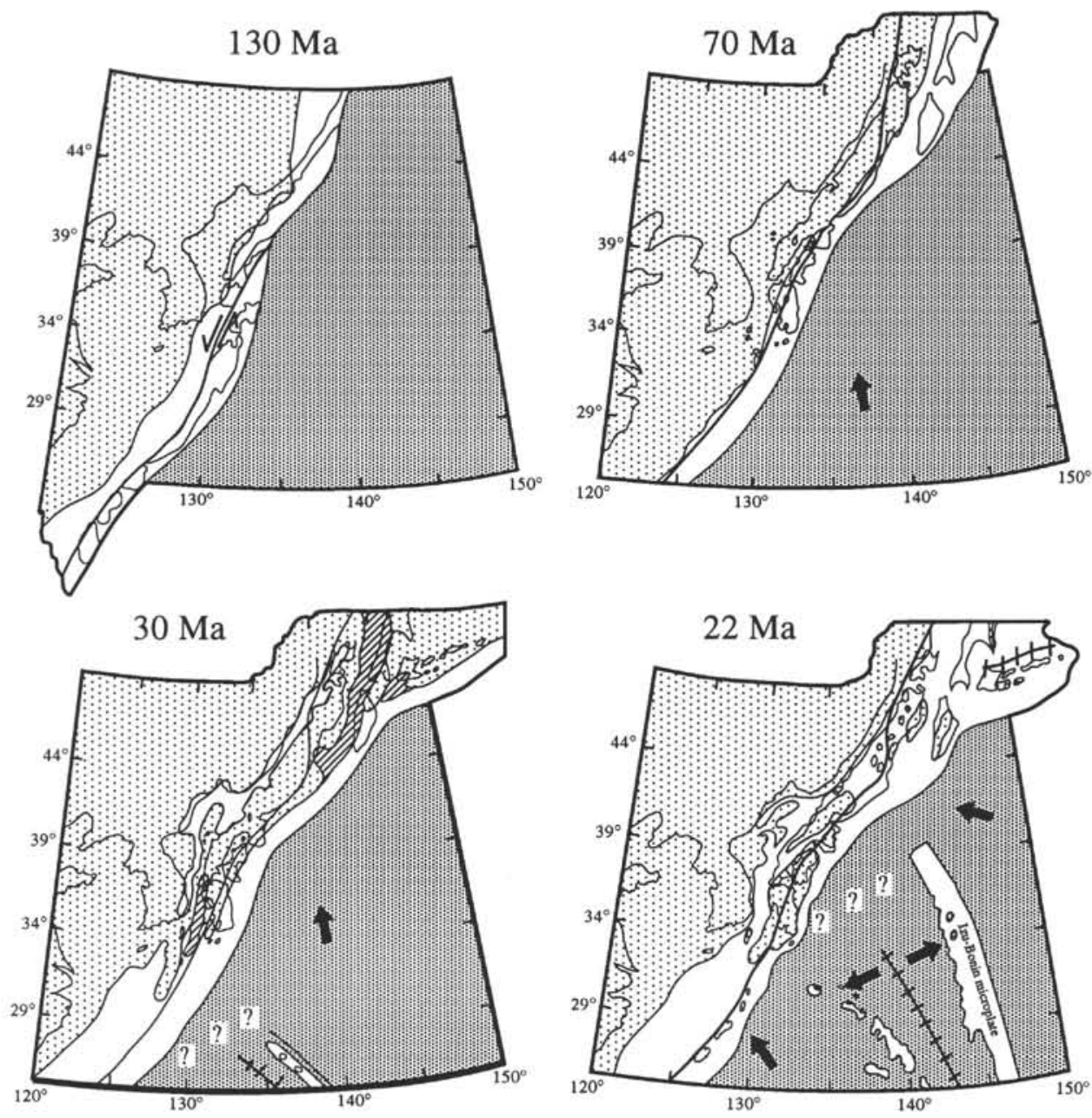

Figure 2. Overview of the plate-tectonic history of the Japanese arcs and Shikoku backarc basin since $130 \mathrm{Ma}$ (adapted from Taira and Ogawa, 1991, with modifications based on Hibbard and Karig, 1990, and Koyama, 1991).

It has not been possible as yet to recognize a provenance for the turbidites, other than one that originally involved axial-trench transport of volcanic-rich material from much farther east in the Izu collision zone (Taira and Niitsuma, 1986). An important aspect of sediment provenance studies in accretionary prisms, exemplified at Site 808 , is the conveyor-belt-like recycling of trench sediments in the trench-landward lower-slope region. Frontal accretion of trench sediments in the accretionary prism is associated with fast rates of uplift and seismogenic activity, leading to large-scale failure of semilithified sediments as sediment slides and debris flows. At Site 808, the upper $20 \mathrm{~m}$ of sediment show overturned and disturbed bedding (Fig. 8 ) in a tongue-like sediment slide also imaged on the IZANAGI sidescan sonar images (Fig. 3). These observations show that sediment is continuously supplied laterally into the trench, although its petrographic provenance indicates an original source in the Izu collision zone and long-distance sediment transport by currents flowing axially along the trench.

\section{Nature and Origin of Acidic Volcaniclastic Deposits at the Base of Site 808}

At Site 808, Unit V (1243.0-1289.9 mbsf; middle Miocene; biozone NN5) is defined by the development of an acidic volcaniclastic unit lying directly upon basaltic basement. The principal lithology in Unit V is varicolored tuffs. The tuffs include (1) a very thick, whitegray, acidic tuff, (2) gray-greenish gray altered tuff, (3) varicolored tuffaceous mudstone (containing foraminifers and calcareous nannofossils), and (4) thin, dark, olive-gray mudstones. The thickness of the tuffs changes from very thin and graded, to very thick-bedded and structureless. Dewatering structures occur below some tuffs as anastomosing, submillimeter dark veins.

The stratigraphic position of Unit V, together with its acidic composition, suggests that it represents an extra-basinal volcanic episode with volcanic centers situated to the north in the Honshu Arc (mainland Japan, the islands of Shikoku and/or Kyushu). The terrigenous-free nature of some of the tuffs suggests emplacement directly through the water column from air-fall rather than by turbidity currents and other sediment gravity flows. The tuffs that contain terrigenous material may have been deposited from subaerial pyroclastic surges that transformed into subaqueous turbidity currents. Whatever their origin, the acidic tuffs do not represent epiclastic deposits. Contemporaneous volcanic activity is known from various parts of the Honshu Arc-for example, the approximately 14- to 13.8-Ma granites in Kyushu and the Kodama acidic volcanics of Kii Peninsula.

\section{General Sedimentological Trends at Site 808}

Detailed descriptions of the downhole trends in clay mineralogy and geochemistry are summarized by Underwood et al. (this volume) and Pickering et al. (this volume). The sedimentology can be summarized as follows: 

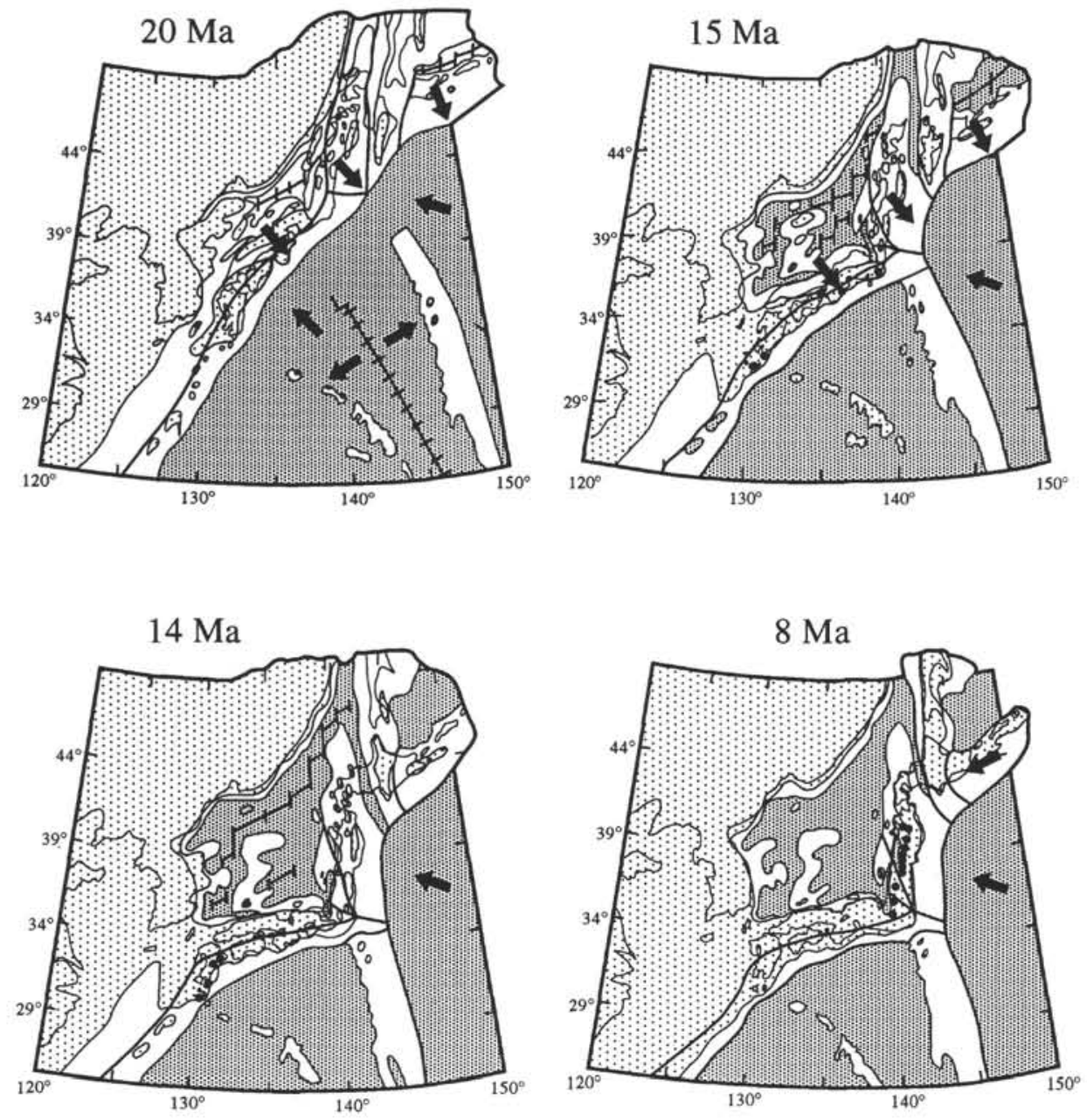

Figure 2 (continued).

1. The overall stratigraphy at Site 808 displays the classic coarsening-upward sequence observed in many subduction zone systems (Piper et al., 1973; von Huene, 1974; Seeley et al., 1974; Dickinson and Seely, 1979), from the slowly accumulating pelagic and hemipelagic sediments overlying the subducting oceanic crust, through first terrigenous thin-bedded, fine-grained turbidites of the outer trench wedge, to more axially deposited, rapidly accumulating, coarse-grained terrigenous sands, and finally a carapace of sediment slide deposits of the accretionary prism slope.

2. In the vicinity of Site 808 , the Nankai Trough appears to have acted as an "under-supplied" linear basin or trench (i.e., one in which the axially flowing turbidity currents had their bedload and sandy suspended sediment load confined within the trench), with overspill only of the muddy suspended load to form the hemipelagic deposits of the Shikoku Basin floor. In contrast, sandy, terrigenous turbidity currents overspilled the confines of the trench into the bathymetrically deeper parts of the backarc basin at the western and eastern ends.

3 . Sand petrography, clay mineralogy, precise characterization of the detrital illite population, and paleocurrent analyses all support the Izu collision zone at the eastern end of Nankai Trough as the principal sediment source. (See also Chamley, 1980; Chamley et al., 1986; Harold and Moore, 1975.) In the trench, axially flowing turbidity currents appear to have been deflected and reflected away from the outer trench and, by extrapolation, from the inner trench slopes, to produce paleocurrents with flow directions (based on the azimuths of current-ripple lee surfaces) back toward the trench axis from the open-ocean backarc basin (Pickering et al., this volume).
4. The geochemistry of the ashes is consistent with known explosive andesitic to rhyolitic volcanism in the Japanese Honshu and Izu-Bonin arcs (Pouclet et al., 1986; Masuda et al., this volume). The geochemistry of the circa-14-Ma rhyolitic pyroclastics at the base of Site 808 is different than for the overlying, younger ashes and tuffs, which suggests a different provenance.

5. Shipboard (Shipboard Scientific Party, 1991c) and subsequent shore-based analyses of the detrital clay fraction show that the hemipelagic and turbiditic muds, together with the matrix in the sandy and silty turbidites, are all enriched in illite, chlorite, and smectite, in decreasing order of abundance, respectively, and with subordinate amounts of kaolinite (Underwood et al., this volume). Values of illite crystallinity index are consistent with a sediment source area characterized by advanced anchimetamorphism and epimetamorphism (Underwood et al., this volume).

6. Shore-based chemical analyses of the hemipelagic mudstones (Pickering et al., this volume) show that they are relatively uniform throughout most of the section. An exception is the metalliferous brown mud between 1087 and 1111 mbsf, which is enriched in $\mathrm{Ca}$, $\mathrm{Fe}, \mathrm{Mg}$, and $\mathrm{Mn}$ oxides (which show up even when normalized to $\mathrm{Al}$, to account for varying concentrations of clay minerals) and is also rich in trace and rare earth elements (e.g., $\mathrm{Ba}, \mathrm{Sr}, \mathrm{S}, \mathrm{Ce}, \mathrm{La}, \mathrm{Y}$ ), interpreted to be the result of precipitation from hydrothermal fluids in a brine over the Shikoku Basin backarc spreading center. These sediments appear similar to ophiolitic umbers (cf. Robertson and Hudson, 1974) with concentrations of carbonate minerals. At oceanridge spreading centers, ferromanganoan oxyhydroxides, occurring 

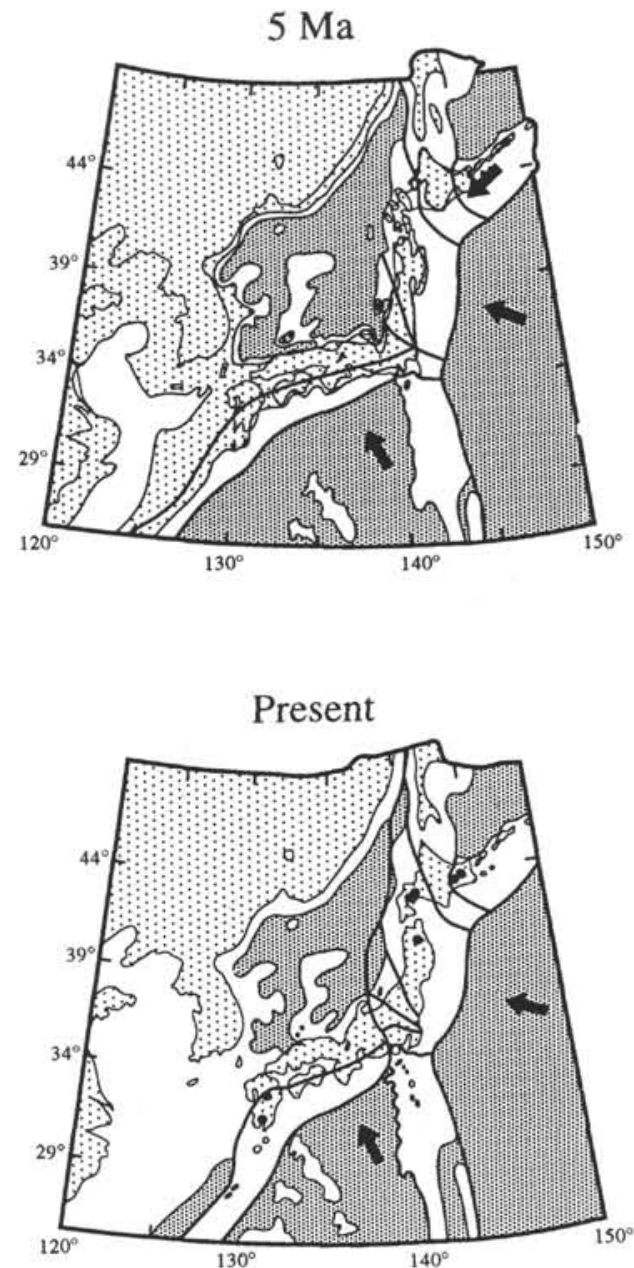

Figure 2 (continued).

as deep-sea nodules or crusts, readily accommodate the rare earth elements (Fleet, 1984).

7. The Upper Shikoku Basin sediments show an increase in smectite content beginning at about $560 \mathrm{mbsf}$ down to $820 \mathrm{mbsf}$, a function of both an enhanced phase of explosive volcanism relative to the younger sediments above, and greater abundance levels compared to the Lower Shikoku Basin unit, probably because the burial temperatures in this part of the prism are high enough to promote the transformation of smectite to illite (Underwood et al., this volume).

8. At about $555 \mathrm{mbsf}$, the detrital and/or authigenic smectite component begins to show a transformation to the illite/smectite mixed-layer clay, the illitization occurring at approximately $65^{\circ} \mathrm{C}$. Loosely bound and structurally bound water is driven off. The lowered pore-fluid chloride concentrations below $650 \mathrm{mbsf}$ in the Shikoku Basin hemipelagic deposits are due in part to in-situ dehydration of clays, but more importantly to advection of fluids from further inside the prism (Gieskes et al., this volume).

9. Site 808 appears to have been near the lysocline and/or below the carbonate compensation depth (CCD) during at least part of its history, based on the paucity of preserved foraminifer and calcareous nannofossils in certain intervals in the Miocene-Pliocene sections. Site 808, however, contains very thin carbonate layers (some of which have been diagenetically altered) in the Shikoku Basin Subunits IVa and IVb, which may have been originally sourced as dilute turbidity currents from the relatively shallower water chalks along the flanks of the paleo-Kyushu-Palau Ridge.

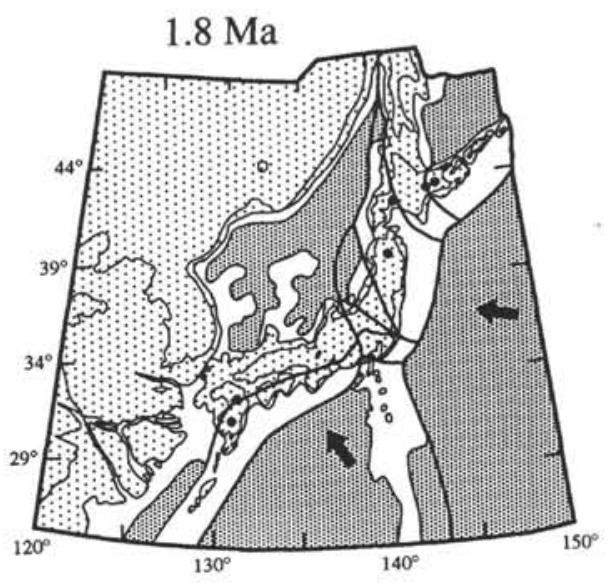

\section{PREVIOUS DSDP SITES IN THE NORTHERN SHIKOKU BASIN AND NANKAI TROUGH}

Previous drilling in the area of ODP Site 808 included Sites 582 and 583 within the Nankai Trough (DSDP Leg 87; Kagami, Karig, Coulbourn, et al., 1986), Site 298 on the lower inner slope of the Nankai Trough (DSDP Leg 31, Karig, Ingle, et al., 1975), and within the Shikoku Basin Sites 297, 296 (DSDP Leg 31; Karig, Ingle, et al., 1975), 442, 443, and 444 (DSDP Leg 58; Klein, Kobayashi, et al. 1980). The stratigraphy of these sites is summarized in the following sections.

\section{DSDP Site 582, Nankai Trough}

At DSDP Site $582,700.9 \mathrm{~m}$ of Holocene-Pliocene sediments were drilled which comprise two lithologic units (Fig. 9). Unit I (Quaternary; 0-566 mbsf) consists of sandy and muddy sand turbidites interbedded with hemipelagic muds; the graded sands show the most easily recognizable Bouma divisions occurring between 360 and $470 \mathrm{mbsf}$. This unit corresponds most closely to Subunit IIc (outer marginal trench deposits) and Unit III (trench-basin transitional deposits) at Site 808. Furthermore, the graded turbidites, in which the basal sand layer grades up into silts and clays, contain an intervening mud (silt) devoid of ichnogenera, suggesting rapid deposition of this interval. In contrast, Chondrites is common in the clay (clayey silt silty clay). The descriptions of such turbidites from Site 582 suggest 


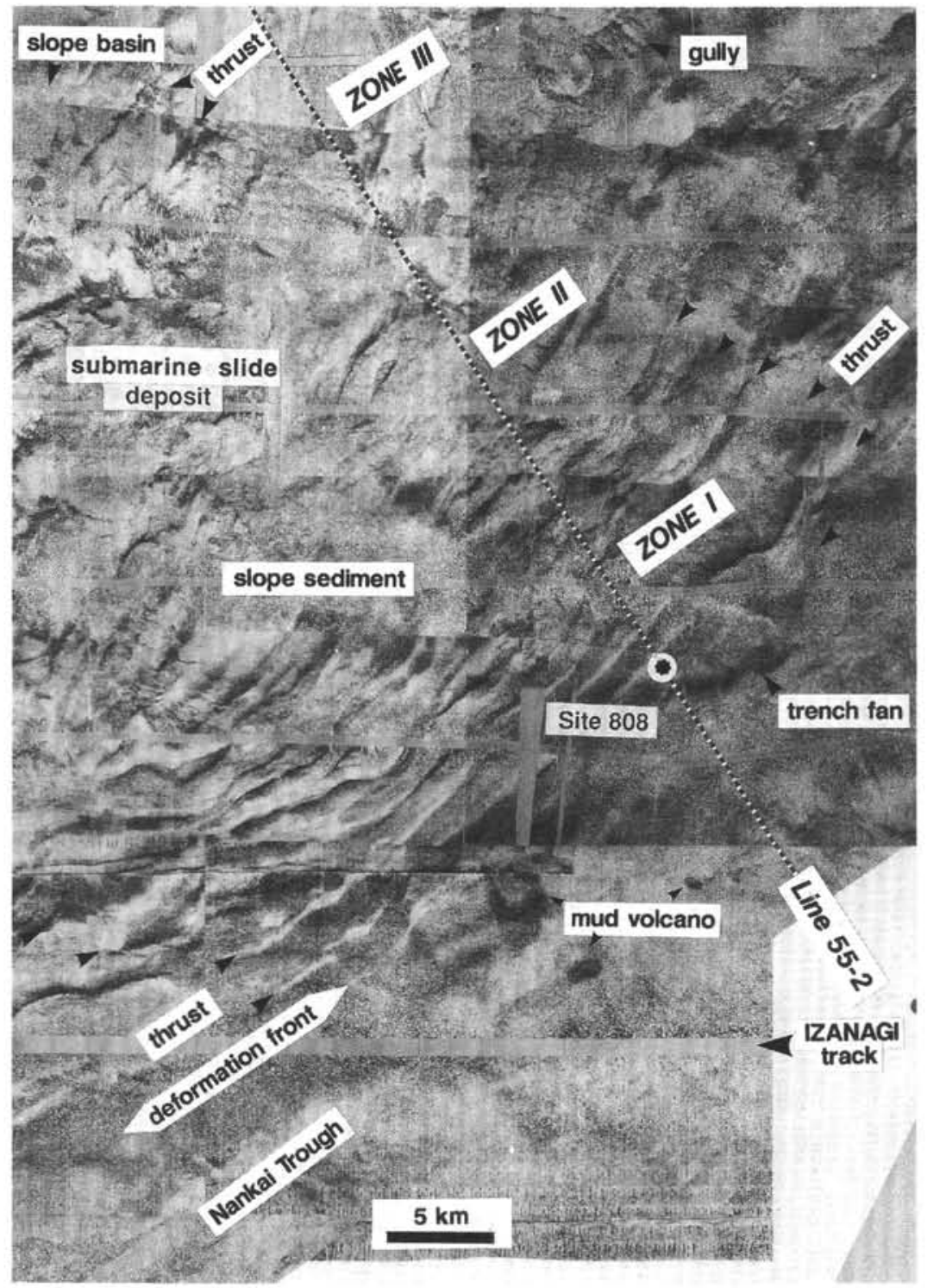

Figure 3. ODP Leg 131 IZANAGI sidescan sonar image of site-survey area, showing position of Site 808 . Note the regularly spaced thrusts cutting the lower slope of the accretionary prism and the evidence of diapirism as mud volcanoes.

that these beds are the same as the unusual ripple-laminated beds described in Subunit IIc and Unit III from Site 808. Unit II (upper Pliocene-Quaternary; 566-701 mbsf) contains hemipelagic, greenish, varicolored, bioturbated muds and lacks graded turbidite beds. Zoophycos and Planolites ichnogenera dominate the succession, unlike the overlying Chondrites-rich parts of Unit I. In such respects, Unit II at Site 582, interpreted as Shikoku Basin deposits (Kagami, Karig, Coulbourn, et al., 1986), corresponds well with the lithologies in Subunit IVa at Site 808.

\section{DSDP Site 583, Nankai Trough}

At DSDP Site 583, 439.7 m of Quaternary sediments were drilled on the lowest structural terrace of the landward slope of the Nankai Trough. The recovered sediments were interpreted as similar to those of lithofacies Unit I at Site 582 (Fig. 9), and comprise olive-gray hemipelagic muds and sandy muds, and sands with common plant debris (Coulbourn, 1986). Large pumice clasts, ash-rich blebs, and deformed ash layers occur throughout the core.

Core recovery at Site 583 was very poor; therefore, detailed lithofacies analysis was not possible. Coulbourn (1986) suggested that a facies change between Sites 582 and 583 may exist, with Site 583 containing thin-bedded, fine-grained, turbidites from the slope or as overbank deposits from turbidity currents flowing along the axis of the Nankai Trough.

\section{DSDP Site 298, Lower Inner Slope of the Nankai Trough}

At DSDP Site 298, $611 \mathrm{~m}$ of Holocene to lower Quaternary sediments were drilled which comprise two units (Fig. 9): Unit 1 (Holocene-upper Quaternary; 0-194 mbsf) contains cobble-bearing muddy sand, interbedded with silty clay, and Unit 2 (lower Pleistocene; 194-611 mbsf) includes fissile claystone and muddy sandstone. The cobbles in Unit 1 are irregular-shaped clasts up to $10 \mathrm{~cm}$ long, 




Figure 4. A. Bathymetric map of the Nankai Trough in the area of Site 808 off southern Shikoku, showing the location of the seismic reflection profiles NT62-8 and KT84-15 L1. Bathymetric contour interval is $100 \mathrm{~m}$, labeled in kilometers below sea level. B. Migrated seismic reflection profile NT62-8 (perpendicular to the trench axis) and line KT84-15 Ll (parallel to the trench axis and in four adjoining panels) show trench-wedge turbidites and oceanic basement partitioning the trench into an eastern and western basin until the Quaternary burial by the high-volume sandy turbidite system of the subducting Shikoku Basin extinct spreading center. Numbers along seismic lines are reference shotpoints to tie lines in (A) to the seismic sections in (B). See text for explanation. TWT $=$ two-way travel time in seconds.

and consist of silty claystone, calcareous sandstone, and limestone (Karig, Ingle, et al., 1975). Not one of these cobble-bearing lithologies were recovered in the comparable intervals at Site 808.

The summary lithologic log for Site 298 suggests that the sands occur in significant amounts to about $230-240 \mathrm{mbsf}$, and possibly to 260-270 mbsf. This depth would correspond roughly to the base of Subunit IIb as defined for Site 808 (i.e., the base of the sandy trench-fill above the outer-trench marginal sediments; Subunit IIc).

\section{DSDP Site 297, Shikoku Basin}

Site 297 is the nearest Shikoku Basin drill site to Site 808. A total of $680 \mathrm{~m}$ of sediments were drilled, which comprise five lithologic units (Fig. 9): Unit 1 (0-54 mbsf) is upper Quaternary diatom and ash-rich clay; Unit 2 (54-90 mbsf) is lower-upper Quaternary clayrich nannofossil ooze; Unit 3 (90-330 mbsf) is upper Pliocene claystone; Unit 4 (330-570 mbsf) is lower Pliocene claystone with interbedded graded silt and sand, containing terrigenous frosted quartz grains, silt, and fine plant debris; and Unit 5 (570-697.5 mbsf) is lower to middle Miocene fine vitric ash/tuff and ash/tuff-rich claystones. In the vicinity of Site 297 , the inferred depth to basement is $780 \mathrm{mbsf}$ (Karig, Ingle, et al., 1975; Shipboard Scientific Party, 1975).

Although a few turbidites with mixed terrigenous and volcanic detritus were recovered in Hole 808C (Subunit IVa), they appear to be more common at Site 297. At Site 297, the upper Pliocene, graded, terrigenous turbidites occurring between 330 and 570 mbsf appear to be age-equivalents to the few volcanic-terrigenous sandstones recovered at Site 808 , Subunit IVa, including a clastic dike at about 814 mbsf. The increase in abundance of these sandstones toward the west-southwest, from Site 808 to Site 297, suggests that the locus of sedimentation was located close to the Kyushu-Palau Ridge, probably because Site 808 was a topographic high, close to the spreading ridge axis of the Shikoku Basin. Coarse-grained turbidity currents therefore tended to be deflected away from this high.

\section{DSDP Site 296, Shikoku Basin}

Site 296, also within the Shikoku Basin, is situated to the southwest of Site 297 on a northwest/west-trending structural bench or terrace near the northern part of the Kyushu-Palau Ridge. Drilling 
B

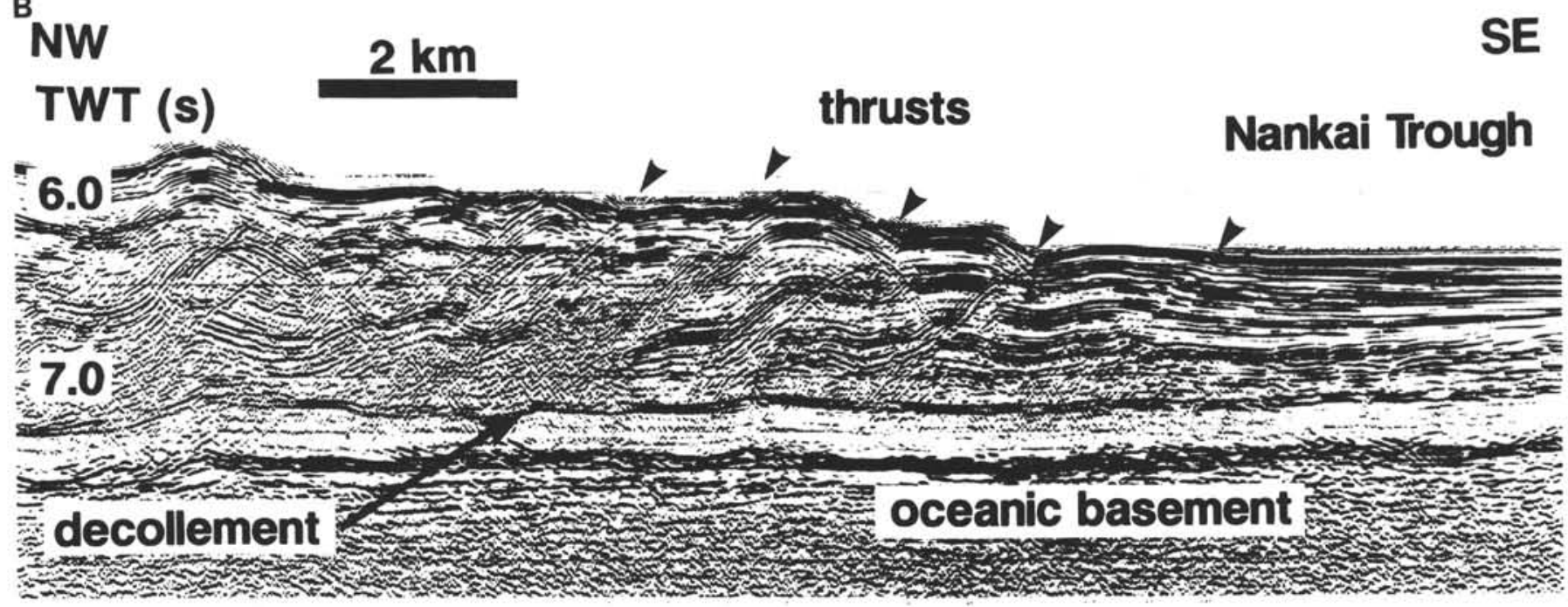

\section{Line NT62-8}

Figure 4 (continued).



Top oceanic basement

Figure 4 (continued).

penetrated $1087 \mathrm{~m}$ of sediments, divided into eight subunits: Unit $1 \mathrm{~A}$ (0-45 mbsf) is Holocene-lower Pleistocene foraminifer-rich nannofossil clay; Unit IB (45-64 mbsf) is lower Pleistocene foraminifer/ clay-rich nannofossil ooze; Unit 1C (64-92 mbsf) is upper Pliocenelower Quaternary clay/micritic carbonate-rich nannofossil ooze; Unit 1D (92-206 mbsf) is upper Miocene-upper Pliocene clayey nannofossil ooze/chalk; Unit 1E (206-282 mbsf) includes lower/upper Miocene clayey nannofossil ooze/chalk with radiolarians and radiolarian-rich zones; Unit $1 \mathrm{~F}$ (282-344 mbsf) is upper Oligocenelower Miocene clayey nannofossil chalk; Unit $1 \mathrm{G}$ (344-453 mbsf) is upper Oligocene clay-rich nannofossil chalk with extensive ash, ashy chalk, and clayey ash interbeds, and Unit 2 (453-1087 mbsf) is lower(?)-upper Oligocene volcanic tuffs, lapilli tuffs, and volcanic sandstones and siltstones. Compared to Site 808, Site 296 spans a greater time period, at least to the late Oligocene rather than late early Miocene. Also, chalks are common at Site 296, as it was shallower than Site 808 and clearly above the CCD.

\section{DSDP Site 442, Shikoku Basin}

DSDP Leg 58 drilled three sites in the central part of the Shikoku Basin. Site 442 consisted of Hole $442 \mathrm{~A}$, drilled to $314 \mathrm{mbsf}$, of which $286 \mathrm{~m}$ were sediments, whereas the deep-basalt-penetration
Hole 442B only took three sediment cores, starting at 269 mbsf with basalt at 290 mbsf. The site comprises five sedimentary lithologic units (Fig. 9): in Hole 442A, Unit 1 (0-164 mbsf) includes PlioceneQuaternary dark greenish gray mud and clay; Unit II, (164-209 mbsf) is upper Miocene-Pliocene yellow-brown to dark brown muds; Unit III (209-277 mbsf) contains two subunits, Subunit IIIa of yellow-brown muds with siliceous fossils and Subunit IIIb of gray, dark greenish muds and ash; Unit IV (277-286 mbsf) is lower-middle Miocene dark brown bioturbated clays and claystones with zeolites; and Unit V is a 40-cm-thick lower Miocene micritic pink limestone overlying basaltic basement at 286 mbsf.

\section{DSDP Site 443, Shikoku Basin}

At Site $443,457 \mathrm{~m}$ of sediments were drilled which were divided into five lithologic units (Fig. 9). Unit I has two subunits, Subunit Ia ( $0-45 \mathrm{mbsf})$ which is Quaternary mud, and Subunit Ib (45-121 mbsf) which is Quaternary calcareous nannofossil mud to clayey nannofossil ooze. Unit II, also divided into two subunits, contains Subunit IIa (121-178 mbsf) of Pliocene ash, clays, and muds, and Subunit IIb (178-207 mbsf) is Miocene-Pliocene clays and muds. Unit III (207-264 mbsf) is upper Miocene clayey nannofossil oozes and muds. Unit IV contains two subunits: Subunit IVa (264-314 mbsf) is 


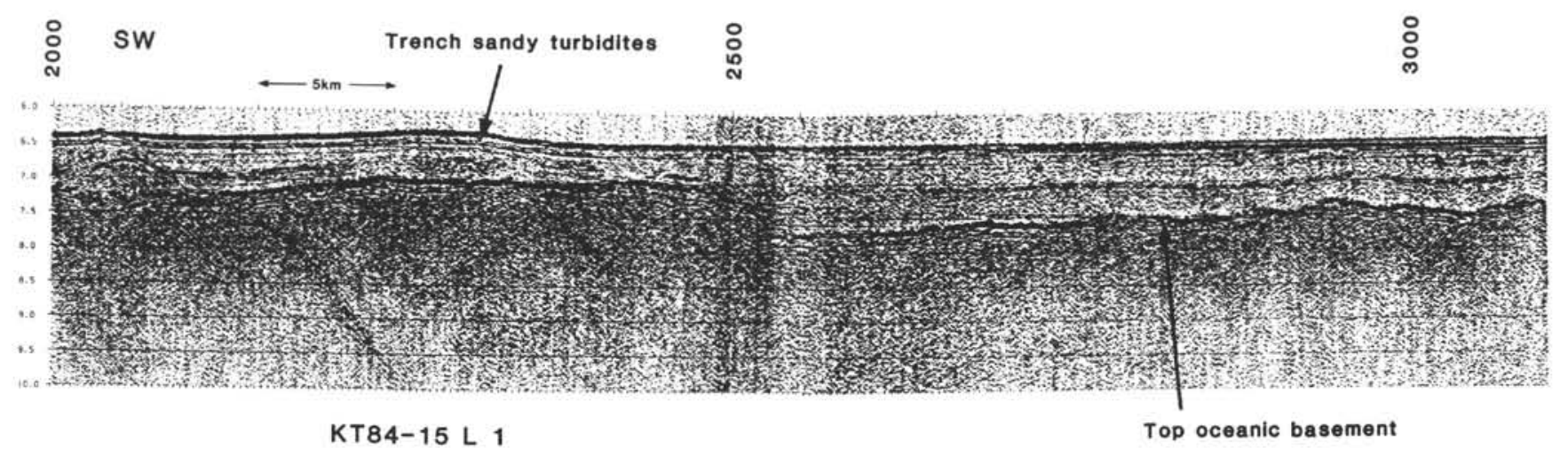

Figure 4 (continued).

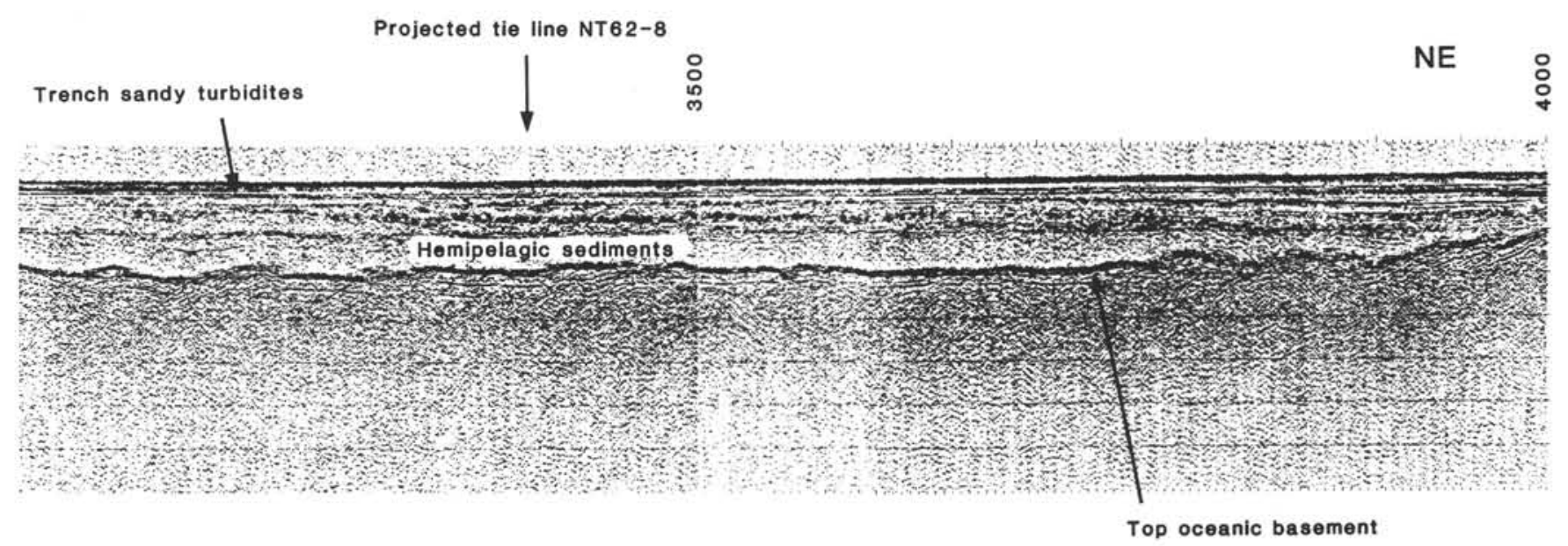

Figure 4 (continued).

middle to upper Miocene mudstones, and Subunit IVb (314-359 mbsf) is middle Miocene mudstones and nannofossil chalks. Unit V (359-457 mbsf) is lower to middle Miocene claystones, mudstones, nannofossil chalk, and ash.

\section{DSDP Site 444, Shikoku Basin}

At Site $444,310 \mathrm{~m}$ of sediments and basement were drilled. As with Site 443, Site 444 was divided into five lithologic units (Fig. 9). Unit I contains two subunits: Subunit Ia (0-27 mbsf) is Quaternary muds and vitric muds, and Subunit $\mathrm{Ib}(27-48 \mathrm{mbsf})$ is Pliocene-Quaternary vitric muds, muds, and calcareous muds. Unit II (48-84 mbsf) is upper Miocene-Pliocene muds and vitric muds. Unit III contains two subunits: Subunit IIIa (86-120 mbsf) is upper Miocene-Pliocene muds, ash, vitric muds, and calcareous and siliceous muds, and Subunit IIIb (120-159 mbsf) is upper Miocene muds, siliceous muds, and pumice. Unit IV comprises three subunits: Subunit IVa (159-196 mbsf) is middle and upper Miocene muds, ash, nannofossil ash, and siliceous muds, Subunit IVb (196-229 mbsf) is middle Miocene mudstones, ash, vitric, and siliceous and calcareous mudstones, and Subunit IVc (229-241 mbsf) is middle Miocene claystones, mudstones, and rare sandstones.

About 12 m of basalt separate Unit IV from Unit V. Unit V (253-273 mbsf) is possibly lower to middle Miocene siliceous and calcareous mudstones and ash, with the lowest meter as zeolitic, calcareous, pelagic claystones, and nannofossil oozes. The three Shikoku Basin sites drilled during DSDP Leg 58 show a typical hemipelagic/pelagic stratigraphy in common with the deeper Shikoku Basin deposits of Subunits IVa and IVb drilled at Site 808.

\section{SEQUENCE STRATIGRAPHY OF NANKAI TROUGH AND THE EXXON EUSTATIC SEA-LEVEL CURVE}

The Exxon "eustatic" sea-level curve (Haq et al., 1987) shows a number of major high-frequency variations which supposedly occur within the past approximately $14 \mathrm{~m} . \mathrm{y}$. represented by the stratigraphy of the four DSDP/ODP sites in the area of the northern Shikoku Basin and Nankai Trough. No clear correlation appears to exist between the major invoked lowstands in eustatic sea level and the timing of the influx of sandy terrigenous turbidites. The onset of coarse sand accumulation at Site 808 , about $300 \mathrm{ka}$, occurred during the last major glacio-eustatic fall in sea level; therefore, it seems reasonable to infer that this was a contributary factor, but not the cause, of this increase in sediment caliber. The notion that sand flux at active collisional margins occurs independently of high and low sea-level stands has been proposed by Klein (1984, 1985a, 1985b, 1985c), but we believe that the reality is commonly more complex. For example, parts of the Pliocene-Pleistocene forearc basin (up to $3.5 \mathrm{~km}$ thick) of the Kazusa Group, southeast Japan, show a good glacio-eustatic signature, especially during the middle Pleistocene when maximum rates of subsidence were less than $2 \mathrm{~m} / \mathrm{k}$.y. and glacio-eustatic sea-level changes were up to $3 \mathrm{~m} / \mathrm{k} . \mathrm{y}$. (Ito, 1992; Pickering and Taira, in press).

The only reliable, and testable, measure of any potential changes in glacio-eustatic sea level comes from the stable oxygen isotope data 


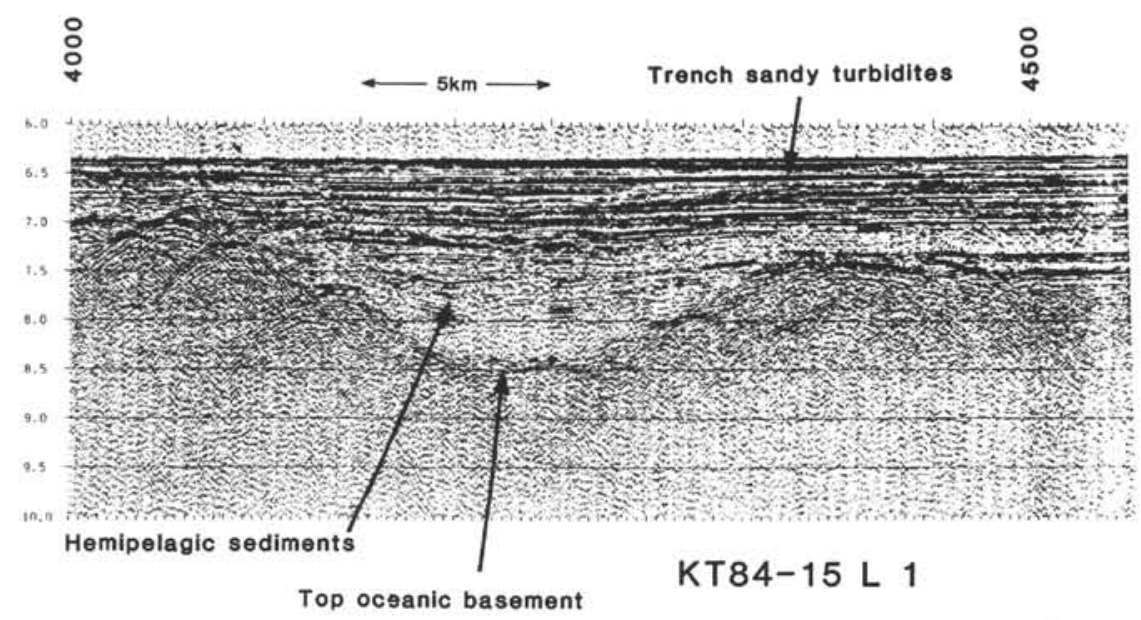

Figure 4 (continued).

for both planktonic and benthic foraminifers from ODP Site 677 in the low-latitude Pacific Ocean (e.g., Shackleton et al., 1990). This record for the past $2.6 \mathrm{Ma}$, although filtered to reveal the effects of changes in the obliquity of the ecliptic (approximately 41-k.y. cycle) and the axial precession (approximately 19-23-k.y. cycle), modulated by eccentricity variations (approximately 100-k.y. cycle) in the Earth's orbit, shows only one major change in isotopic signature at about $0.8-0.9 \mathrm{Ma}$, commensurate with the onset of the last major Antarctic glaciation. The 0.8-0.9-Ma cooling of both the Pacific bottom and surface waters is revealed as a shift to more negative oxygen isotope values (Shackleton et al., 1990, fig. 7). This event, also shown on the Exxon "eustatic" curve as the last major sea-level fall (Haq et al., 1987), does not appear to be picked out clearly in the stratigraphy at Site 808, nor at the other DSDP/ODP sites.

A graph of age vs. depth (Fig. 5) shows significant changes in sediment accumulation rates at very different time periods, that is, $0.46 \mathrm{Ma}$ (increasing up), 1.66-1.89 Ma (increasing up), $5 \mathrm{Ma}$ (increasing up), 7.5 Ma (increasing up), and $11 \mathrm{Ma}$ (decreasing up). These inflection points on the curve, reflecting upward-increasing rates of sediment accumulation, are best interpreted as a consequence of tectonic processes superimposed on the Shikoku Basin oceanic plate approaching the Nankai Trough. The one significant decreasing-upward rate of sediment accumulation, at about $11 \mathrm{Ma}$, probably reflects the initial relatively fast sedimentation in the Shikoku Basin spreading ridge area associated with the final (tectonic) rifting phase to about 13.6-14 Ma, after which the rate decreased with the onset of slow, open-ocean, hemipelagic deposition.

In summary, tectonic processes exert the first-order control on the overall coarsening-upward sequence, from open-ocean pelagic/hemipelagic to terrigenous turbidites of the trench wedge. At the scale of the overall coarsening-upward stratigraphy, any eustatic changes are masked, and therefore are second-order phenomenon, only recognized by high-resolution chemostratigraphic and biostratigraphic techniques beyond the resolution of this study.

\section{DEPOSITIONAL MODELS FOR TRENCH AND FOREARC}

The sedimentology, stratigraphy, and tectonics of the northern Shikoku Basin and Nankai Trough area suggest the following as major features of any integrated depositional model for this forearc/ backarc basin:
1. Trench sedimentation cannot be reconstructed satisfactorily as a two-dimensional model from the accretionary prism, through the trench to the open-ocean basin. Any proposed depositional models must account for the complex three-dimensional architecture of the sedimentary environments.

2. Tectonics exert the primary control on changing rates of sediment supply; in this low-latitude region, climatic changes, although undoubtedly exerting some influence, are very much a secondary control. In the Shikoku Basin stratigraphy, the upward decrease in the rate of sediment accumulation seen at many of the sites reflects the change from rifting to the cessation of rifting, and the corresponding reduction in bathymetric relief of the rifted arc and remnant-arc fragments.

3. Early in the evolution of the Shikoku Basin, the bathymetrically high spreading ridge partitioned the basin into a western and eastern sector.

4. The subducting extinct Shikoku Basin ocean spreading center (ridge) has exerted a fundamental control on trench bathymetry and, therefore, the manner in which the axially supplied sandy turbidite wedge infills the trench. The trench is topographically higher over the subducting ridge, with significantly deeper basins to either side. In order to bury this topographic barrier and permit coarse, sand-rich, turbidity currents to flow over the site of the subducting ridge crest, sediment supply rates, or the sediment flux must be very high. At Site 297, the Pliocene terrigenous turbidites were restricted to the southwest of the Shikoku Basin spreading center, and any terrigenous sands that travelled from the Suruga Trough, in the east-northeast, do not appear to have overspilled the ridge. The Pliocene turbidites at Site 297 were restricted to the western Shikoku Basin, and probably came from Ashizuri Canyon at the western end of Shikoku (which lacks volcanoes and is, therefore, a better candidate source for the more quartzo-feldspathic sands), or via canyons from Kyushu (see also detailed petrographic studies that support this contention in Marsaglia et al., in press).

5. At the base of Site 808 , immediately overlying the basaltic oceanic basement, the prominent pyroclastic unit is rhyolitic in composition, both as primary fall and reworked material, and the rocks are geochemically different to the overlying, younger ashes and tuffs. These rhyolitic tuffs may be associated with the circa-14-13.8-Ma igneous activity in Kyushu and Honshu as seen, for example, on Kii Peninsula where there are contemporaneous granites and pyroclastics. The acidic pyroclastics at Site 808 appear to be subaqueous in origin, and may even have come from submerged explosive centers 
to give reworked, sediment gravity-flow deposits. At Site 297, the Miocene volcaniclastics may also be related to this same rhyolitic magmatism. Restoring the location of Sites 808 and 297 to their respective positions about $14 \mathrm{Ma}$, using present plate-convergence rates and vectors, does not significantly affect the possibility of an acidic igneous source at the land sites in Kii Peninsula and Kyushu. The latter source would have been closer to both Sites 808 and 297 in the middle Miocene.

6. Sediment provenance and sediment dispersal pathways can be defined (Fig. 10) as volcaniclastic sources from the active Izu-Bonin island arc in the east (e.g., DSDP Sites 443 and 444), a western volcaniclastic and carbonate-mantled source from the Kyushu-Palau Ridge (e.g., DSDP Site 442), and a northern (mainly northeastern) mixed terrigenous and volcaniclastic source from the Kyushu and western Honshu area (e.g., DSDP Site 297) and the Izu collision zone (e.g., ODP Site 808) (Fig. 10). Finally, turbidity currents travelling along the axis of the trench, or from flows coming off the accretionary prism laterally, can be deflected and reflected against the basin slopes to give locally complex paleocurrent patterns (Pickering et al., this volume).

\section{ACKNOWLEDGMENTS}

The manuscript has benefited from the helpful reviews by George deVries Klein, F. Masuda, and an anonymous reviewer.

\section{REFERENCES*}

Boggs, S., Jr., 1984. Quaternary sedimentation in the Japan arc-trench system. Geol. Soc. Am. Bull., 95:669-685.

Chamley, H., 1980. Clay sedimentation and paleoenvironment in the Shikoku Basin since the middle Miocene (Deep Sea Drilling Project Leg 58, North Philippine Sea). In Klein, G.deV., Kobayashi, K., et al., Init. Repts. DSDP, 58: Washington (U.S. Govt. Printing Office), 669-678.

Chamley, H., Cadet, J.-P., and Charvet, J., 1986. Nankai Trough and Japan Trench Late Cenozoic paleoenvironments deduced from clay mineralogic data. In Kagami, H., Karig, D.E., Coulbourn, W.T., et al., Init. Repts. DSDP, 87: Washington (U.S. Govt. Printing Office), 633-641.

Chamot-Rooke, N., Renard, V., and Le Pichon, X., 1987. Magnetic anomalies in the Shikoku Basin: a new interpretation. Earth Planet. Sci. Lett., 83:214-228.

Collot, J.-Y., Daniel, J., and Burne, R.V., 1985. Recent tectonics associated with the subduction/collision of the d'Entrecasteaux zone in the central New Hebrides. Tectonophysics, 112:325-356.

Coulbourn, W.T., 1986. Sedimentologic summary, Nankai Trough Sites 582 and 583, and Japan Trench Site 584. In Kagami, H., Karig, D.E., Coulbourn, W.T., et al., Init. Repts. DSDP, 87: Washington (U.S. Govt. Printing Office), 909-926.

Dickinson, W.R., and Seely, D.R., 1979. Structure and stratigraphy of forearc regions. AAPG Bull., 63:2-31.

Fisher, M.A., Collot, J.-Y., and Smith, G.L., 1986. Possible causes for structural variation where the New Hebrides island arc and the d'Entrecasteaux zone collide. Geology, 14:951-954.

Fleet, A.J., 1984. Aqueous and sedimentary geochemistry of the rare earth elements. In Henderson, P. (Ed.), Rare Earth Element Geochemistry: New York (Elsevier), 343-373.

Haq, B.U., Hardenbol, J., and Vail, P.R., 1987. Chronology of fluctuating sea levels since the Triassic. Science, 235:1156-1167.

Harold, P.J., and Moore, J.C., 1975. Composition of deep-sea sands from marginal basins of the northwestern Pacific. In Karig, D.E., and Ingle, J.C., Jr., et al., Init. Repts. DSDP, 31: Washington (U.S. Govt. Printing Office), 507-514.

Hibbard, J.P., and Karig, D.E., 1990. Structural and magmatic response to spreading ridge subduction: an example from southwest Japan. Tectonics, 9:207-230.

Ito, M., 1992. High-frequency depositional sequences of the upper part of the Kazusa Group, a middle Pleistocene forearc basin fill in Boso Peninsula, Japan. Sediment. Geol., 76:155-175.

* Abbreviations for names of organizations and publications in ODP reference lists follow the style given in Chemical Abstracts Service Source Index (published by American Chemical Society).
Kagami, H., 1985. Internal structures of the accretionary wedge in the Nankai Trough off Shikoku, southwestern Japan. In Nasu, N., Kobayashi, K., Uyeda, S., Kushiro, I., and Kagami, H. (Eds.), Formation of Active Ocean Margins: Tokyo (Terra Sci. Publ.), 193-219.

Kagami, H., Karig, D.E., Coulbourn, W.T., et al., 1986. Init. Repts. DSDP, 87: Washington (U.S. Govt. Printing Office).

Kaiko I Research Group, 1986. Taira, A., and Tokuyama, H. (Eds.), Topography and Structure of Trenches Around Japan-Data Atlas of FrancoJapanese Kaiko Project, Phase I: Tokyo (Univ. of Tokyo Press).

Karig, D.E., 1975. Basin genesis in the Philippine Sea. In Karig, D.E., Ingle, J.C., Jr., et al., Init. Repts. DSDP, 31: Washington (U.S. Govt. Printing Office), 857-879.

Karig, D.E., Ingle, J.C., Jr., et al., 1975. Init. Repts. DSDP, 31: Washington (U.S. Govt. Printing Office).

Klein, G. deV., 1984. Relative rates of tectonic uplift as determined from episodic turbidite deposition in marine basins. Geology, 12:48-50.

, 1985a. The control of depositional depth, tectonic uplift and volcanism on sedimentation processes in the back-arc basins of the western Pacific Ocean. J. Geol., 93:1-25.

, 1985b. The frequency and periodicity of preserved turbidites in submarine fans as a quantitative record of tectonic uplift in collision zones. Tectonophysics, 119:181-193.

$-1985 \mathrm{c}$. Sedimentation patterns in relation to rifting, arc volcanism, and tectonic uplift in back-arc basins of the western Pacific Ocean. In Nasu, N., Kobayashi, K., Uyeda, S., Kushiro, I., and Kagami, H. (Eds.), Formation of Active Ocean Margins: Tokyo (Terra Sci. Publ.), 517-549.

Klein, G. deV., Kobayashi, K., et al., 1980. Init. Repts. DSDP, 58: Washington (U.S. Govt. Printing Office).

Koyama, M., 1991. Tectonic evolution of the Philippine Sea Plate based on paleomagnetic results. J. Geogr., 100:628-641. (in Japanese)

Kumon, F., Suzuki, H., Nakazawa, K., Tokuoka, T., Harata, T., Kimura, K., Nakaya, S., Ishigami, T., and Nakamura, K., 1988. Shimanto Belt in the Kii Peninsula, southwest Japan. Mod. Geol., 12:71-96.

Le Pichon, X., Iiyama, T., Chamley, H., Charvet, J., Faure, M., Fujimoto, H., Furata, T., Ida, Y., Kagami, H., Lallemant, S., Leggett, J., Murata, A., Okada, H., Rangin, C., Renard, V., Taira, A., and Tokuyama, H., 1987a. The eastern and western ends of Nankai Trough: results of Box 5 and Box 7 Kaiko survey. Earth Planet. Sci. Lett., 83:199-213.

Le Pichon, X., Iiyama, T., Chamley, H., Charvet, J., Faure, M., Fujimoto, H., Furuta, T., Ida, Y., Kagami, H., Lallemant, S., Leggett, J., Murata, A., Okada, H., Rangin, C., Renard, V., Taira, A., and Tokuyama, H., 1987b. Nankai Trough and the fossil Shikoku Ridge: results of Box 6 Kaiko survey. Earth Planet. Sci. Lett., 83:186-198.

Marsaglia, K.M., Ingersoll, R.V., and Packer, B.M., 1992. Tectonic evolution of the Japanese islands as reflected in modal compositions of Cenozoic forearc and backarc sand and sandstone. Tectonics, 11:1028-1044.

Miyake, Y., 1985. MORB-like tholeiites formed within the Miocene forearc basin, southwest Japan. Lithos, 18:23-34.

Moore, G.F., Karig, D.E., Shipley, T.H., Taira, A., Stoffa, L., and Wood, W.T., 1991. Structural framework of the ODP Leg 131 area, Nankai Trough. In Taira, A., Hill, I., Firth, J.V., et al., Proc. ODP, Init. Repts., 131: College Station, TX (Ocean Drilling Program), 15-20.

Moore, G.F., and Shipboard Scientific Party, 1991. Underway geophysics. In Taira, A., Hill, I., Firth, J.V., et al., Proc. ODP, Init. Repts., 131: College Station, TX (Ocean Drilling Program), 21-24.

Moore, G.F., Shipley, T.H., Stoffa, P.L., Karig, D.E., Taira, A., Kuramoto, S., Tokuyama, H., and Suyehiro, K., 1990. Structure of the Nankai Trough accretionary zone from multichannel seismic reflection data. J. Geophys. Res., 95:8753-8765.

Moore, J.C., and Karig, D.E., 1976. Sedimentology, structural geology, and tectonics of the Shikoku subduction zone, southwestern Japan. Geol. Soc. Am. Bull., 87:1259-1268.

Murauchi, S., and Asanuma, T., 1974. Seismic reflection profiles and sonobuoy refraction measurements during GDP-6 to -8 voyages. Mar. Sci., 6:23-27. (in Japanese)

, 1977. Seismic Reflection Profiles in the Western Pacific, 19651974: Tokyo (Univ. Tokyo Press).

Okuda, Y., and Honza, E., 1988. Tectonic evolution of the Seinan (SW) Japan fore-arc and accretion in the Nankai Trough. Mod. Geol., 12:411-434.

Pickering, K.T., and Taira, A., in press. Tectonosedimentation; with examples from the Tertiary of southern Japan. In Hancock, P.L. (Ed.), New Concepts in Tectonics. Int. Union Geophys. Sci. Publ.

Piper, D.J.W., von Huene, R., and Duncan, J.R., 1973. Late Quaternary sedimentation in the active eastern Aleutian Trench. Geology, 1:19-22. 
Pouclet, A., Fujioka, K., Charvet, J., and Cadet, J.-P., 1986. Petrography and geochemistry of volcanic ash layers from Leg 87A, Nankai Trough (South Japan). In Kagami, H., Karig, D.E., Coulbourn, W.T., et al., Init. Repts. DSDP, 87: Washington (U.S. Govt. Printing Office), 695-701.

Robertson, A.H.F., and Hudson, J.D., 1974. Pelagic sediments in the Cretaceous and Tertiary history of the Troodos Massif, Cyprus. In Hsü, K.J., and Jenkyns, H.C. (Eds.), Pelagic Sediments: On Land and Under the Sea: Spec. Publ. Int. Assoc. Sedimentol., 403-436.

Schweller, W.J., and Kulm, L.D., 1978. Depositional patterns and channelized sedimentation in active eastern Pacific trenches. In Stanley, D.J., and Kelling, G. (Eds.), Sedimentation in Submarine Canyons, Fans, and Trenches: Stroudsburg (Dowden, Hutchinson, and Ross), 323-350.

Seely, D.R., Vail, P.R., and Walton, G.G., 1974. Trench slope model. In Burk, C.A., and Drake, C.L. (Eds.), The Geology of Continental Margins: Berlin (Springer-Verlag), 249-260.

Shackleton, N.J., Berger, A., and Peltier, W.R., 1990. An alternative astronomical calibration of the lower Pleistocene timescale based on ODP Site 677. Trans. R. Soc. Edinburgh, Earth Sci., 81:251-261.

Shimamura, K., 1989. Topography and sedimentary facies of the Nankai deep sea channel. In Taira, A., and Masuda, F. (Eds.), Sedimentary Facies in the Active Plate Margin: Tokyo (Terra Sci. Publ.), 529-556.

Shipboard Scientific Party, 1975. Site 297. In Karig, D.E., Ingle, J.C., Jr., et al., Init. Repts. DSDP, 31: Washington (U.S. Govt. Printing Office), 275-316.

, 1991a. Explanatory notes. In Taira, A., Hill, I., Firth, J.V., et al., Proc. ODP, Init. Repts., 131: College Station, TX (Ocean Drilling Program), 25-60.

, 1991b. Geological background and objectives. In Taira, A., Hill, I., Firth, J.V., et al., Proc. ODP, Init. Repts., 131: College Station, TX (Ocean Drilling Program), 5-14.

1991c. Site 808. In Taira, A., Hill, I., Firth, J.V., et al., Proc. ODP, Init. Repts., 131: College Station, TX (Ocean Drilling Program), 71-272.
Soh, W., Pickering, K.T., Taira, A., and Tokuyama, H., 1990. Basin evolution in the arc-arc Izu Collision Zone, Mio-Pliocene Miura Group, central Japan. J. Geol. Soc. London, 148:317-330.

Taira, A., 1986. Newton, 6:56-87.

Taira, A., Hill, I., Firth, J.V., et al., in press. Proc. ODP, Init. Repts., 131: College Station, TX (Ocean Drilling Program).

Taira, A., and Niitsuma, N., 1986. Turbidite sedimentation in the Nankai Trough as interpreted from magnetic fabric, grain size, and detrital modal analyses. In Kagami, H., Karig, D.E., Coulbourn, W.T., et al., Init. Repts. DSDP, 87: Washington (U.S. Govt. Printing Office), 611-632.

Taira, A., and Ogawa, Y., 1991. Cretaceous to Holocene forearc evolution in Japan and its implication to crustal dynamics. Episodes, 14:205-212.

Taira, A., Okada, H., Whitaker, J.H.McD., and Smith, A.J., 1982. The Shimanto Belt of Japan: Cretaceous-lower Miocene active-margin sedimentation. In Leggett, J.K. (Ed.), Trench-forearc Geology. Geol. Soc. London Spec. Publ., 10:5-26.

Thornburg, T.M., and Kulm, L.D., 1987. Sedimentation in the Chile Trench: depositional morphologies, lithofacies and stratigraphy. Geol. Soc. Am. Bull., 98:33-52.

Underwood, M.B., 1991. Submarine canyons, unconfined turbidity currents, and sedimentary bypassing of forearc regions. Rev. Aquat. Sci., 4:149-200.

White, S.M., Chamley, H., Curtis, D., Klein, G deV., Mizuno, A., and Fountain, D.M., 1980. Sediment synthesis: Deep Sea Drilling Project Leg 58, Philippine Sea. In Klein, G. deV., Kobayashi, K., et al., Init. Repts. DSDP, 58 : Washington (U.S. Govt. Printing Office.), 963-1013.

\footnotetext{
Date of initial receipt: 28 May 1992

Date of acceptance: 21 October 1992

Ms 131SR-135
}

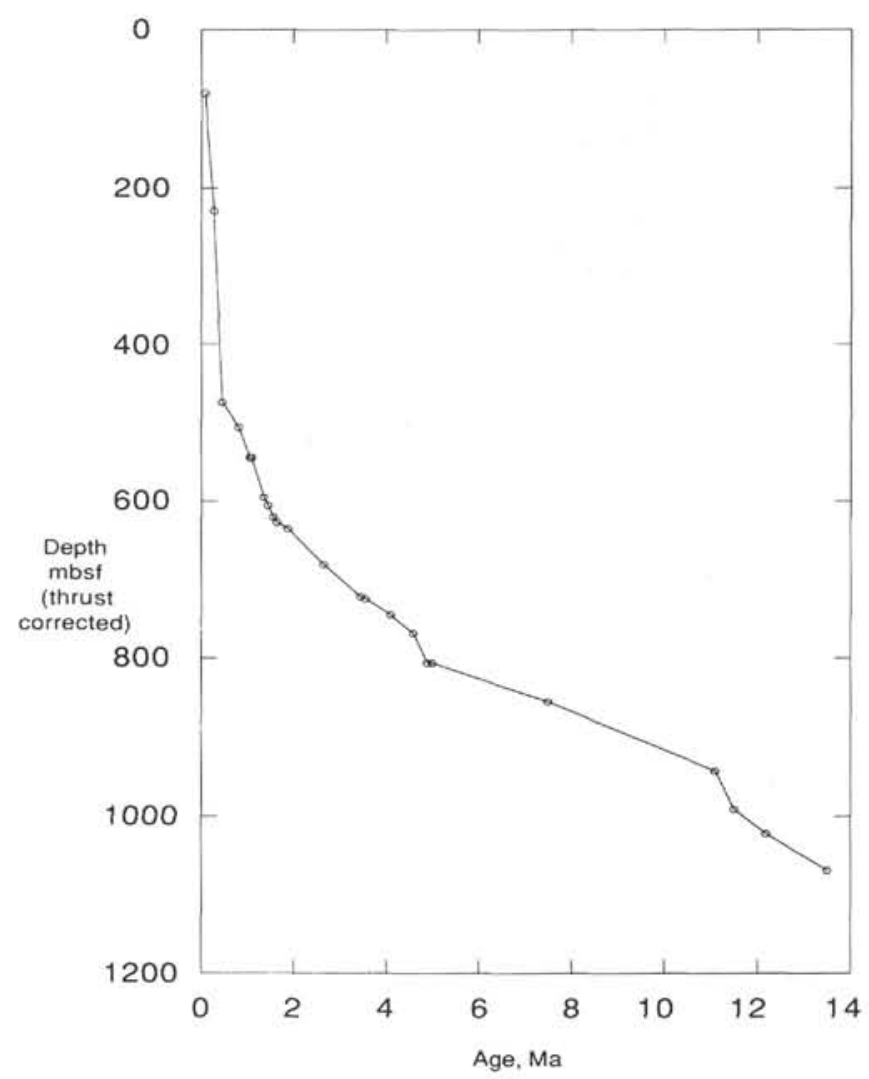

Figure 5. Bio-age vs. depth chart for ODP Site 808, showing inflection points indicating changes in the rate of sediment supply (see also Olafsson, this volume). Overall, sediment supply rates increase in a stepwise manner upward, caused by the northward-moving Shikoku Basin oceanic plate approaching the Nankai Trough and being mantled by trench-wedge turbidites. 


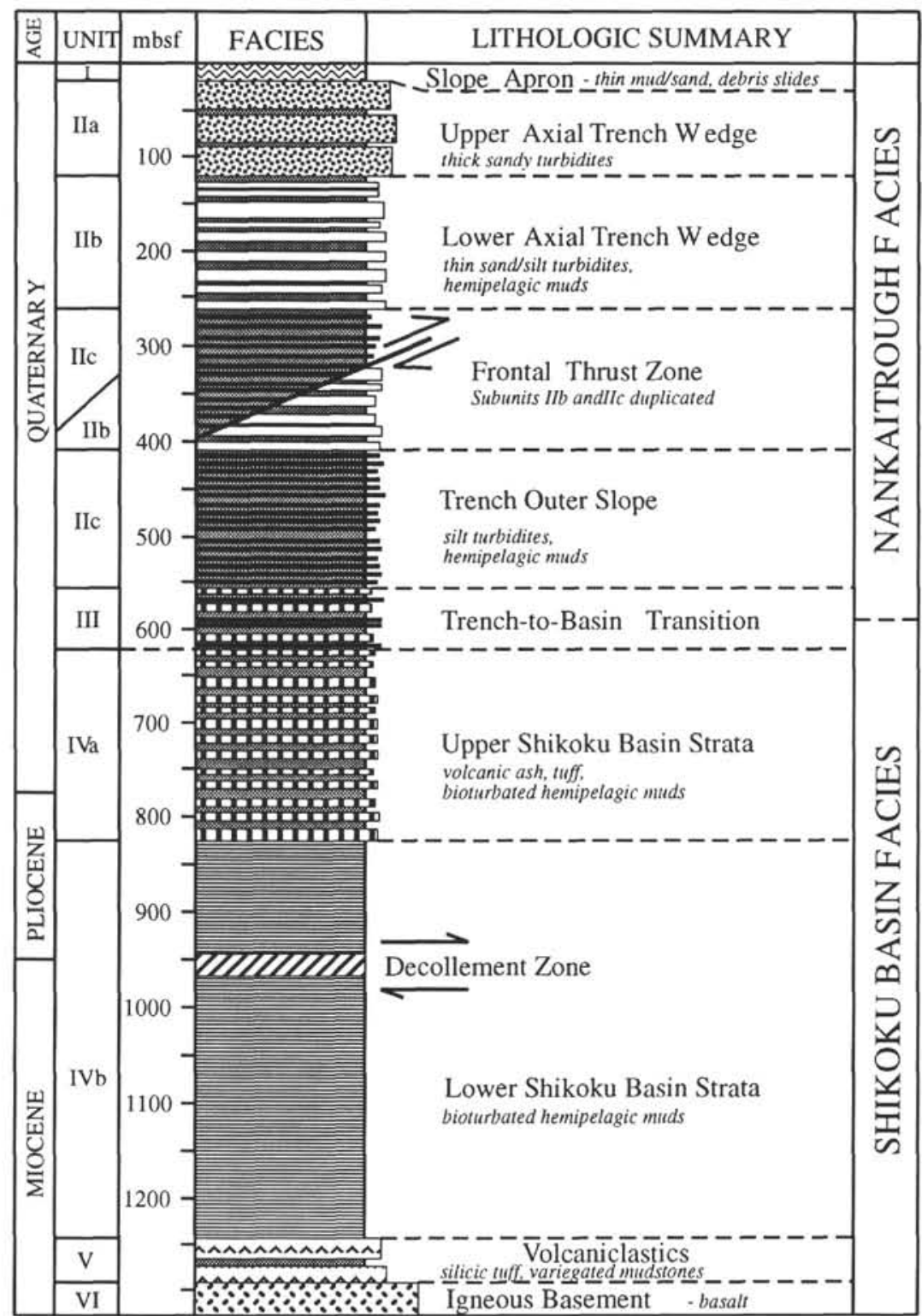

Figure 6. Stratigraphic summary of ODP Leg 131 Site 808 showing classic coarsening-upward sequence from open-ocean basin plain pelagic/hemipelagic mudstones to trench-fill sandy turbidites. 




Figure 7. Core photograph showing comparison of the inferred same, thrustduplicated, matrix-supported mudstone-pebble conglomerate at 263.4 and $409.54 \mathrm{mbsf}$. In agreement with the seismic evidence, the conglomerate suggests a vertical offset of about $145 \mathrm{~m}$ across the frontal thrust. 


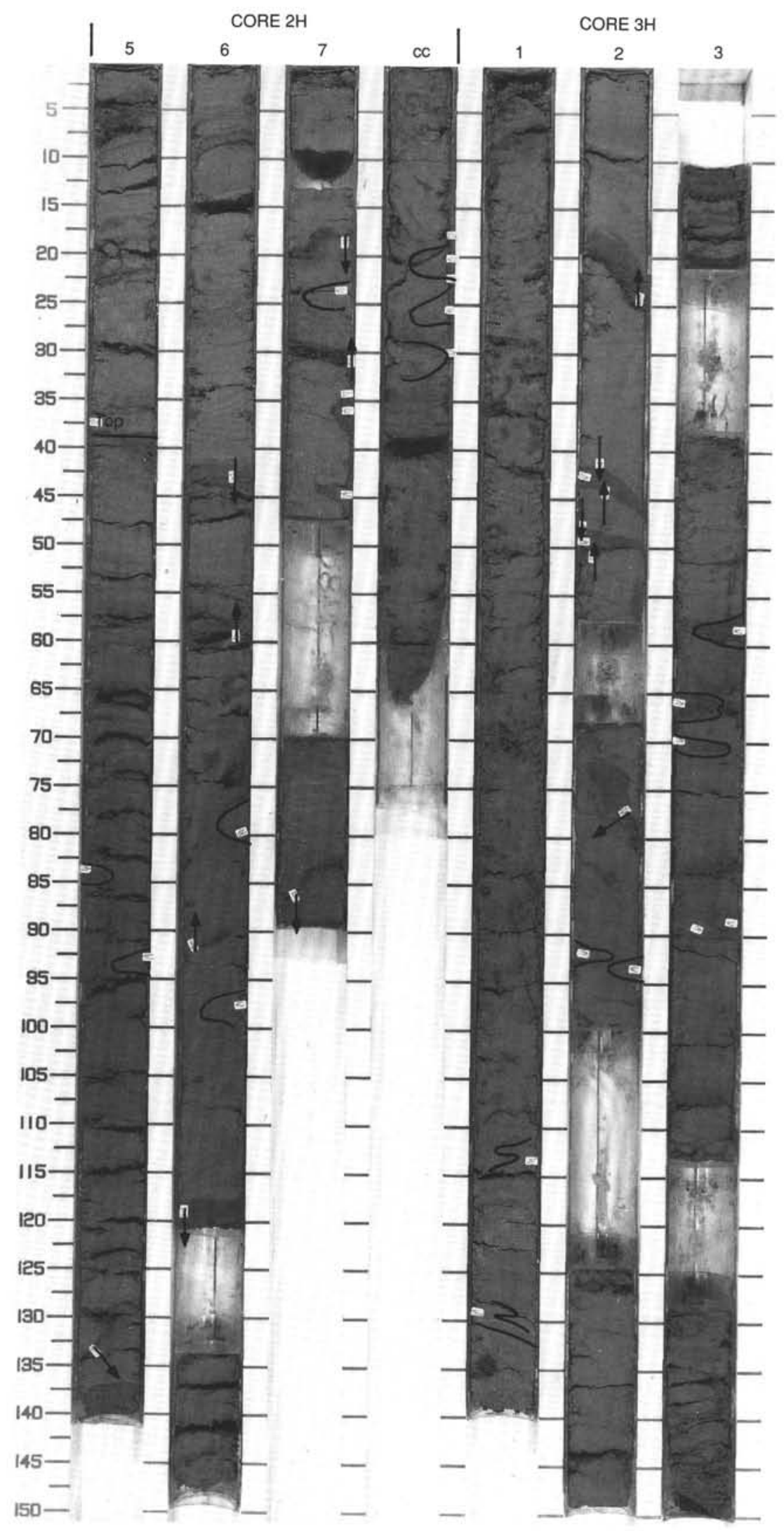

Figure 8. Core photographs showing sediment slide deposits in the uppermost part of the stratigraphy at Site 808 , to 20.20 mbsf. Line interpretation of fold closures and facing directions of bedding. Arrows point toward stratigraphic tops. 

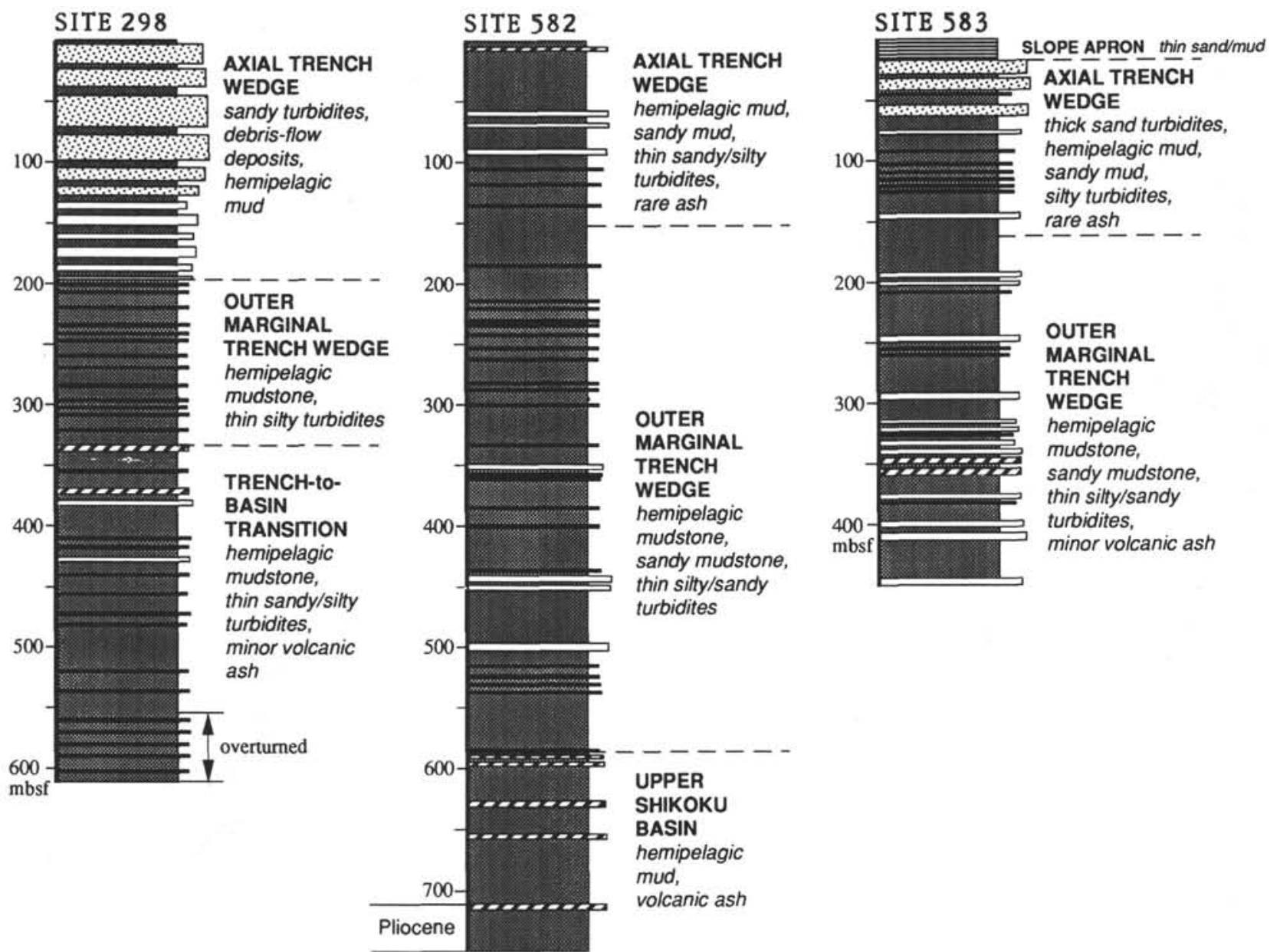

Figure 9. Stratigraphic summary of DSDP Sites 582 and 583 (Nankai Trough), Site 298 (Nankai Trough, lower slope of accretionary prism), Sites 296 and 297 (western Shikoku Basin), and Sites 442, 443 and 444 (eastern Shikoku Basin). 


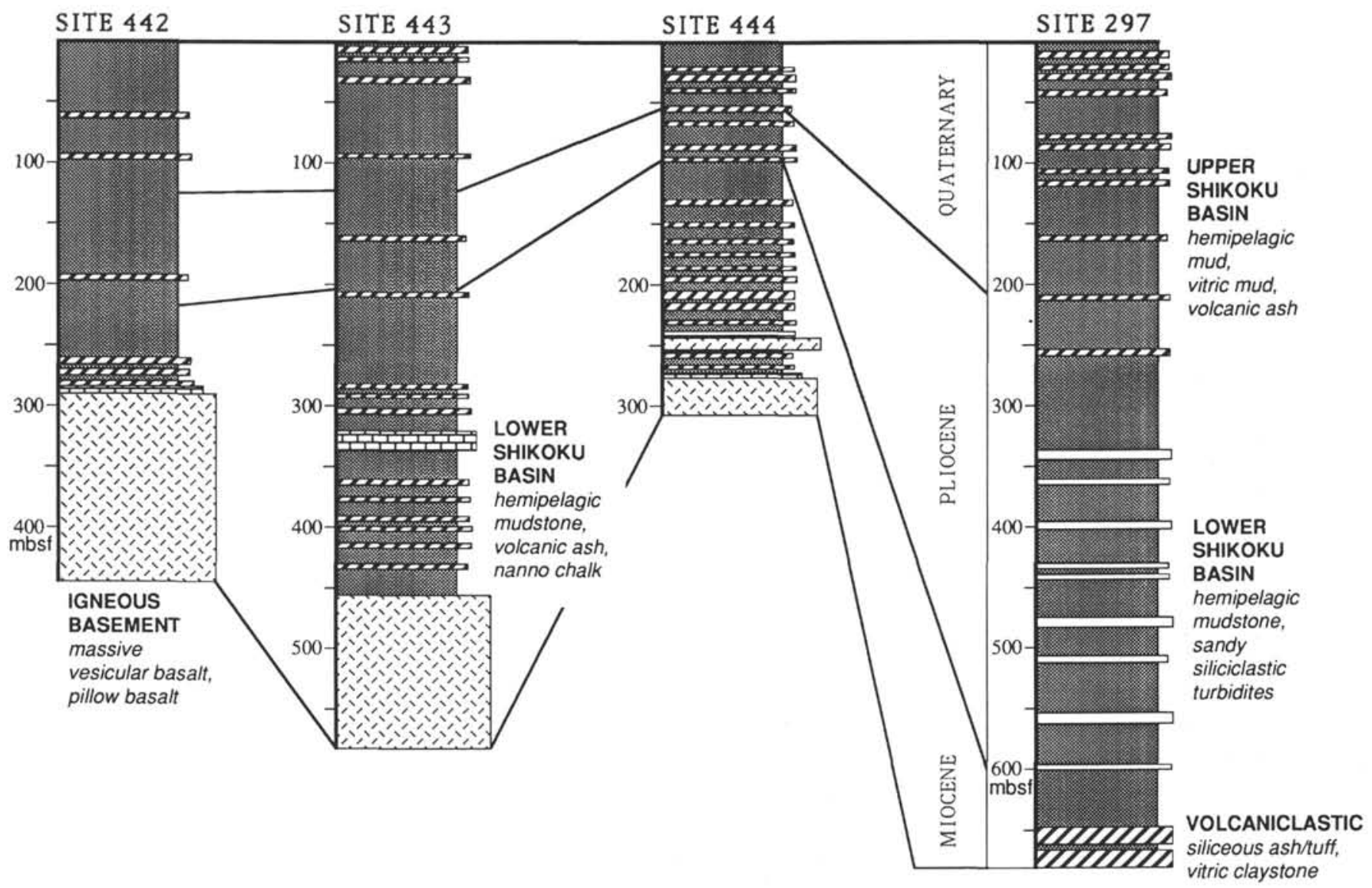

Figure 9 (continued).

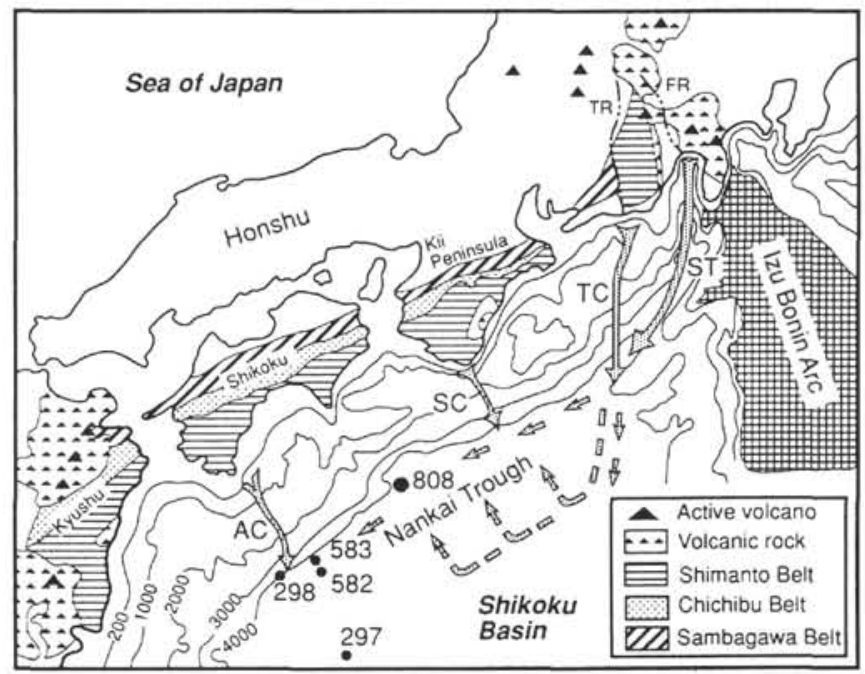

Figure 10. Location map of Site 808, Nankai Trough, showing the major sediment entry points: $\mathrm{ST}=$ Suruga Trough, $\mathrm{TC}=$ Tenryu Canyon, $\mathrm{SC}=$ Shiono-misaki Canyon, and $\mathrm{AC}=$ Ashizuri Canyon. 